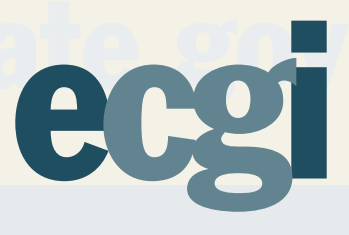

\title{
Market soundings: the interaction between securities regulation and company law in the United Kingdom and Italy
}

Law Working Paper N 362/2017

August 2017
Stefano Lombardo

Free University of Bozen/Bolzano, CRELE and ECGI

\section{Federico M. Mucciarelli}

University of Modena and SOAS

(C) Stefano Lombardo and Federico M. Mucciarelli 2017. All rights reserved. Short sections of text, not to exceed two paragraphs, may be quoted without explicit permission provided that full credit, including (C) notice, is given to the source.

This paper can be downloaded without charge from: http://ssrn.com/abstract_id=3012183

www.ecgi.org/wp 


\section{Market soundings: the interaction between securities regulation and company law in the United Kingdom and Italy}

Working Paper N 362/2017

August 2017

Stefano Lombardo

Federico M. Mucciarelli

We would like to thank Renzo Costi, Nicholas Foster, Sergio Gilotta, Paolo Giudici, Chiara Mosca, Mathias Siems and Giovanni Strampelli for their helpful comments and suggestions. We are, of course, the only persons responsible for omissions or mistakes. This article has been conceived, discussed and elaborated together by the authors; for the purpose of academic evaluation it has to be mentioned that Sections 3 and 4 were written by Stefano Lombardo while Sections 2 and 5 were written by Federico M. Mucciarelli; Sections 1 and 6 were written by the authors together.

(C) Stefano Lombardo and Federico M. Mucciarelli 2017. All rights reserved. Short sections of text, not to exceed two paragraphs, may be quoted without explicit permission provided that full credit, including (C) notice, is given to the source. 


\begin{abstract}
Before deciding on operations involving share issuance or sale, companies or shareholders may seek to disclose information to selected investors, in order to gauge their opinion on the envisaged market operation. Such 'market soundings' risk violating the prohibition of insider trading and yet such selective disclosures have been partially accepted in several European jurisdictions. Market soundings have been recently regulated in the Market Abuse Regulation, which clarifies under which circumstances they are allowed and the position of the involved parties. This Article analyses the rules on market soundings in the Market Abuse Regulation with regard to initial public offers of securities, issuance in the secondary market and accelerated bookbuildings. Additionally, it will be stressed that market soundings might also violate national company law rules and principles, mostly those related to directors' duties and liabilities. This Article addresses how Italian and English company law regimes react towards selective disclosures. It will be shown that a tension may still exist between national company law rules and uniform rules on the prohibition of market abuses.
\end{abstract}

Keywords: market soundings, insider trading, company law, securities regulation, European Union, Italy, United Kingdom

JEL Classifications: G38, K22

\author{
Stefano Lombardo* \\ Associate Professor of Economic Law \\ Free University of Bozen/Bolzano, Faculty of Economics and Management \\ Piazza Universita 1 \\ 39100 , Bozen, Italy \\ phone: +390471 013491 \\ e-mail: stefano.lombardo@unibz.it \\ Federico M. Mucciarelli \\ Associate Professor of Business Law \\ University of Modena, Department of Economics \\ Viale Berengario 51 \\ 41100 Modena, Italy \\ phone: +390592056778 \\ e-mail: federicomaria.mucciarelli@unimore.it
}

*Corresponding Author 


\title{
Market soundings: the interaction between securities regulation and company law in the United Kingdom and Italy
}

24 July 2017

Stefano Lombardo - Federico M. Mucciarelli*

\begin{abstract}
Before deciding on operations involving share issuance or sale, companies or shareholders may seek to disclose information to selected investors, in order to gange their opinion on the envisaged market operation. Such 'market soundings' risk violating the probibition of insider trading and yet such selective disclosures have been partially accepted in several European jurisdictions. Market soundings have been recently regulated in the Market Abuse Regulation, which clarifies under which circumstances they are allowed and the position of the involved parties. This Article analyses the rules on market soundings in the Market Abuse Regulation with regard to initial public offers of securities, issuance in the secondary market and accelerated bookbuildings. Additionally, it will be stressed that market soundings might also violate national company law rules and principles, mostly those related to directors' duties and liabilities. This Article addresses how Italian and English company law regimes react towards selective disclosures. It will be shown that a tension may still exist between national company law rules and uniform rules on the probibition of market abuses.
\end{abstract}

Keywords: market soundings, insider trading, company law, securities regulation, European Union, Italy, United Kingdom

* Stefano Lombardo is Associate Professor at the Free University of Bozen/Bolzano (Italy), CRELE and ECGI Research Associate; Federico M. Mucciarelli is an Associate Professor at University of Modena Reggio Emilia (Italy) and a Reader at SOAS, University of London (UK). We would like to thank Renzo Costi, Nicholas Foster, Sergio Gilotta, Paolo Giudici, Chiara Mosca, Mathias Siems and Giovanni Strampelli for their helpful comments and suggestions. We are, of course, the only persons responsible for omissions or mistakes. This article has been conceived, discussed and elaborated together by the authors; for the purpose of academic evaluation it has to be mentioned that Sections 3 and 4 were written by Stefano Lombardo while Sections 2 and 5 were written by Federico M. Mucciarelli; Sections 1 and 6 were written by the authors together. 


\section{INTRODUCTION}

Regulation (EU) No 596/2014, the Market Abuse Regulation (hereinafter MAR) ${ }^{1}$, and Directive 2014/57/EU (hereinafter CRIM-MAD), ${ }^{2}$ which entered into force on July $32016,{ }^{3}$ have replaced the Market Abuse Directive (hereinafter MAD), ${ }^{4}$ regulating insider trading ${ }^{5}$ and market manipulations in the European Union. ${ }^{6}$ While MAR is one of the EU measures aimed at harmonizing national rules that "have as their object the establishment and functioning of the internal market" and provides substantive rules on insider trading and market manipulation, CRIM-MAD is a directive

1 Regulation (EU) No 596/2016 of the European Parliament and the Council of 16 April 2016 on market abuse (market abuse regulation) and repealing Directive 2003/6/EC of the European Parliament and of the Council and Commission Directives 2003/124/EC, 2003/125/EC and 2004/72/EC, OJ 12.6.2014 L173/1.

2 Directive 2014/57/EU of the European Parliament and the Council of 16 April 2016 on criminal sanctions for market abuse (market abuse directive), OJ 12.6.2014, L173/179.

3 As of today, Italy has not adopted national measures for implementing Directive 2014/57/EU.

4 Directive 2003/6/EC of the European Parliament and the Council of 28 January 2003 on insider dealing and market manipulation (market abuse), OJ 12.4.2003 L96/16. This Directive had repealed Council Directive of 13 November 1989 coordinating regulations on insider dealing (89/592/EEC), OJ 18.11.1989 L334/30, on insider trading and introduced a regulation for market manipulation.

5 We use the term 'insider trading' summarizing the offences included in Article 14 MAR.

6 See, C Di Noia, M Milic and P Spatola, 'Issuers' obligations under the new Market Abuse Regulation and the proposed ESMA guideline regime: a brief overview' (2014) 26 Zeitschrift für Bankrecht und Bankwirtschaft 96.

In German see M Kiesewetter and M Parmentier,'Verschärfung des Marktmissbrauchsrechts - ein Überblick über die neue EU-Verordnung über Insidergeschäfte und Marktmanipulation' (2013) 68 Betriebs-Berater 237; C Seibt and B Wollenschläger, 'Revision des Marktmissbrauchsrechts durch Marktmissbrauchsverordnung und Richtlinie über strafrechtliche Sanktionen für Marktmanipulation' (2014) 59 Die Aktiengesellschaft 593; R Veil, 'Europäisches Insiderrecht 2.0 - Konzeption und Grundsatzfragen der Reform durch MAR und CRIM-MAD’ (2014) 26 Zeitschrift für Bankrecht und Bankwirtschaft 85; C H Seibt, 'Revision des Marktmissbrauchsrechts durch Marktmissbrauchsverordnung und Richtlinie über strafrechtliche Sanktionen für Marktmanipulation' (2014) 59 Die Aktiengesellschaft 593; D Poelzig, 'Insiderund Marktmanipulationsverbot im neuen Marktmissbrauchsrecht' (2016) 19 Neue Zeitschrift für Gesellschaftsrecht 52; D Zetzsche, Marktintegrität/Marktmissbrauchsrecht, in M Gebauer and C Teichmann, Enzyklopädie Europarecht Europäisches Privatund Unternehmensrecht, Band 6 (Nomos 2016) 171.

In Italian see, Francesco Mucciarelli, 'L'“insider trading” nella rinnovata disciplina UE sugli abusi di mercato' (2016) 35 Le Società 193; S Lombardo, 'L’informazione privilegiata' (2016) 35 Le Società 147.

Article 114 TFEU. 
aimed at ensuring 'the effective implementation of a Union policy in an area which has been subject to harmonisation measures ${ }^{8}$ and only focuses on criminal sanctions for market abuse. ${ }^{9}$ These two acts are complemented by subordinate legislations, ${ }^{10}$ such as Regulatory Technical Standards (RTS) ${ }^{11}$, Implementing Technical Standards (ITS ${ }^{12}$, proposed by ESMA ${ }^{13}$ and enacted by the Commission, and ESMA guidelines and recommendations. ${ }^{14}$

$8 \quad$ Article 83(2) TFEU.

9 Today's European legislation seeks to increase regulatory uniformity with regard to securities regulation by replacing directives with regulations. For instance, recital 5 of the Prospectus Regulation, which has replaced the Prospectus Directive, states that 'It is appropriate and necessary for the rules on disclosure when securities are offered to the public or admitted to trading on a regulated market to take the legislative form of a regulation in order to ensure that provisions directly imposing obligations on persons involved in offers of securities to the public and in admissions of securities to trading on a regulated market are applied in a uniform manner throughout the Union. Since a legal framework for the provisions on prospectuses necessarily involves measures specifying precise requirements for all different aspects inherent to prospectuses, even small divergences on the approach taken regarding one of those aspects could result in significant impediments to cross-border offers of securities, to multiple listings on regulated markets and to Union consumer protection rules. Therefore, the use of a regulation, which is directly applicable without requiring national law, should reduce the possibility of divergent measures being taken at national level, and should ensure a consistent approach, greater legal certainty and prevent such significant impediments. The use of a regulation will also strengthen confidence in the transparency of markets across the Union, and reduce regulatory complexity as well as search and compliance costs for companies"; Regulation (EU) 2017/1129 of the European Parliament and the Council of 14 June 2017 on the prospectus to be published when securities are offered to the public or admitted to trading on a regulated market, and replacing Directive 20037/71/EC, OJ 30.6.2017 L 168/12.

10 According to the past procedure of the 'Lamfalussy process', on which, see N Moloney, 'The Lamfalussy Legislative Model: a New Era for the EC Securities and Investement Services Regime' (2003) 52 International and Comparative Law Quarterly 509; see also N Moloney, EU Securities and Financial Markets Regulation (Oxford University Press 2014) 26.

11 Delegated acts according to Article 290 TFEU.

12 Implementing acts according to Article 291 TFEU.

13 According to, respectively, Article 10 and Article 15 of Regulation (EU) No 1095/2010 of the European Parliament and of the Council of 24 November 2010 establishing a European Supervisory Authority (European Securities and Markets Authority), amending Decision No 716/2009/EC and repealing Commission Decision 2009/77/EC, in OJ 15.12.2010, L331/84.

14 According to Article 16 of Regulation 1095/2010, guidelines and recommendations can be applied or not by national authorities following a specific procedure. For a list of directives and regulations adopted by the Commission, see ESMA, 2016, Questions and Answer on the Market Abuse Regulation, 13 July 2016, ESMA /2016/1129. For 
The main reason for replacing a directive with a regulation was granting regulatory uniformity and clarity of key concepts throughout the whole territory of the Union. ${ }^{15}$ A uniform regulatory framework was judged to be key to repealing trade obstacles and distortions of competition, which may arise from different national laws, and to developing further the internal capital market. Although the new regulation has introduced some innovative rules (such as the extension of the regulatory scope to MTF and $\mathrm{OTF}^{16}$ or the black-out period for manager transactions ${ }^{17}$ ), it does not change the fundamental logic and structure of the MAD, which proved a coherent and acceptable (albeit not perfect) framework for preventing and enforcing insider trading and market manipulation offences. ${ }^{18}$

One of the innovative provisions of the MAR is Article 11 regulating 'market soundings', which governs the procedure to be followed when a market participant seeks to disclose information to selected investors, in order to gauge their opinion on a possible transaction. ${ }^{19}$ This Article is complemented by the Commission Implementing Regulation (EU) 2016/95920 (hereinafter CIR

the guidelines see, ESMA, 2016, Final Report. Guidelines on the Market Abuse Regulation - market soundings and delay of disclosure of inside information, 13 July 2016, ESMA /2016/1130.

$15 \quad$ MAR recitals 3, 4 and 5.

16 Article 5.1. MAR.

$17 \quad$ Article 19.11. and 19.12. MAR.

18 A comprehensive assessment of the MAD does not fall within the scope of this article.

19 For first comments on market soundings, see SW Tissen, 'Die Investorensuche im Lichte der EUMarktmissbrauchsverordung' (2015) 18 Neue Zeitschrift für Gesellschaftsrecht 1254; S Lombardo, 'I sondaggi di mercato: prime riflessioni' (2016) 35 Le Società 159; Zetzsche, Marktintegrität/Marktmissbrauchsrecht (n 6) at para 210; D Zetzsche, 'Die Marktsondierung nach Art. 11 MAR. Pflichten der Sondierenden und der Marktgegenseite’ (2016) 61 Die Aktiengesellschaft 610.

20 Commission Implementing Regulation (EU) 2016/959 of 17 May 2016 laying down implementing technical standards for market soundings with regard to the systems and notification templates to be used by disclosing market participants and the format of the records in accordance with Regulation (EU) No 596/2014 of the European Parliament and of the Council, OJ 17.6.2016, L160/23. 
2016/959) and Commission Delegated Regulation (EU) 2016/960'21 (hereinafter CDR 2016/906), as 'Level 2' regulations, and by ESMA guidelines, being 'Level 3' implementing rules. ${ }^{22}$

The main reason for the introduction of Article 11 MAR is that offerors commonly need to capture the opinion of potential investors on an envisaged operation, particularly on its pricing, and to attain this goal they are normally requested to disclose pieces of inside information. If we consider offers of securities, a need to sound out potential investors emerges with regard to four types of transaction. In this regard, we intentionally do not address market soundings in mergers and takeover bids, ${ }^{23}$ as this situation would require a specific analysis. Therefore, this work only addresses situations when shares or other securities are offered to the market or selected investors, that is to say: (i) initial public offerings (IPO), namely when a company decides to go public and list on a regulated market; ${ }^{24}$ (ii) secondary offerings (or seasoned offerings), namely when an already listed company seeks to increase its capital; (iii) accelerated bookbuilding, when the offeror is a shareholder; (iv) and accelerated bookbuilding, when a listed company acts as an offeror by selling own shares held as treasury shares or by issuing new shares to selected investors.

At first glance, such an exception to the general prohibition of disclosing information seems to be quite innovative, since no similar provision was included in the Market Abuse Directive. The $\mathrm{MAD}$, in particular, prohibited insiders from disclosing inside information to third parties, unless such a disclosure was 'in the normal course of exercise of an employment, profession or duties' ${ }^{25}$ In that case, the insider must also make 'complete and effective public disclosure' of such information, unless the recipient is bound by a duty of confidentiality based on law, regulations, articles of association or

21 Commission Delegated Regulation (EU) 2016/960 supplementing Regulation (EU) No 596/2014 of the European Parliament and of the Council with regard to regulatory technical standards for the appropriate arrangements, systems and procedures for disclosing market participants conducting market soundings, OJ 17.06.2016, L160/29.

22 ESMA/2016/1130 (n 14).

23 Article 11.2. MAR.

$24 \quad$ Although IPOs can also be launched on non-regulated markets, we will only address those made in regulated markets.

25 MAD Article 3.1(a). 
on a contract. ${ }^{26,27}$ Therefore, under the Market Abuse Directive the question arose as to whether an offeror, by disclosing to selected parties an envisaged operation, was acting in the 'normal course of exercise of an employment, profession or duties'. The European Court of Justice (ECJ) in Grongaard and Bang interpreted these provisions in a quite strict manner. ${ }^{28}$ The Court decided that a piece of information is deemed to be disclosed in the normal course of the exercise of employment, profession or duties only when (i) there is a close link between the disclosure and the exercise of the employment, profession or duties and (ii) the disclosure is strictly necessary for the exercise of that employment, profession or duties. This decision, therefore, does not seem to leave much free space for market sounding, and yet informal contacts between securities' offerors and potential investors are deemed necessary for the success of operations, which would otherwise risk not being accepted by the market once officially announced. Market soundings, therefore, and despite the restrictive case law of the ECJ, have become common practice with regard to several types of transactions related to listed shares.

Market soundings, additionally, may also trigger quite complex company law issues. ${ }^{29} \mathrm{By}$ deciding to communicate an envisaged transaction to only selected investors, directors of the issuing company might reveal such classified and sensitive information to third parties; alternatively, if such information is disclosed to selected shareholders, directors would discriminate other shareholders. In both cases, a decision to disclose an envisaged transaction might be deemed a violation of directors' fiduciary duties. This potential conflict between financial regulation and company law reveals a much broader contradiction. On the one hand, due to the globalisation of financial markets, market actors and regulators are pushed to develop homogeneous practices and rules at the broadest geographical level $;^{30}$ on the other hand, companies' internal affairs are governed by national states and the EU harmonising effort in this field has not touched core elements of companies' internal relations such

26 MAD Article 6.3, second paragraph.

27 As we shall see, the MAR entails identical provisions, together with the general rules governing market soundings: MAR Article 17.8.

28 C-384/02, Grongaard and Bang (n 28).

29 See H Fleischer and D Bedkowski, 'Aktien- und kapitalmarktrechtliche Probleme des Pilot Fishing bei Börsengängen und Kapitalerhöhungen’ (2009) 62 Der Betrieb 2195.

30 See W Streeck, Einleitung: Internationale Wirtschaft, nationale Demokratie?, in W Streeck (ed.), Internationale Wirtschaft, nationale Demokratie (Campus 1998) 11. 
as director duties and liabilities. ${ }^{31}$ Thus, rules on market sounding are at the crossroads of securities regulation, which requires uniformity across national borders, and company law rules, which are rooted in national political balances and legal discourses. Addressing market soundings, therefore, is also a way of addressing the fragmentation of law and society in the new globalized order, which is revealed by the struggle between, on the one hand, the globalising tendencies of financial markets and, on the other hand, local interests whose interests are addressed by national rules. ${ }^{32}$ This article, therefore, aims at unbundling the interaction between national company law and EU securities regulation. As an example of this interaction, the United Kingdom and the Italian national regimes will be compared. The U.K. has a longstanding and highly sophisticated practice in financial market regulation, including market abuses and insider dealings, that reflect the predominance of widely-held companies, so that its regime was one of the models for the provisions detailed in the MAR on market soundings $;{ }^{33}$ in this regard, it is worth stressing that, despite its decision to leave the European Union, the U.K. is likely to keep its role as a benchmark regime. ${ }^{34}$ Italy, by contrast, is a civil law country whose financial market is far less significant than the British one; additionally, share ownership of Italian companies is extremely concentrated and families still keep a dominant role in its economy. ${ }^{35}$

This article is organized as follows. Section 2 provides an analysis of how market soundings were treated in Italy and the U.K. before the introduction of the MAR. Section 3 focus on an overview

31 See C Gerner-Beuerle and E Schuster, 'The Evolving Structure of Director Duties in Europe’ (2014) 15 European Business Organization Law Review 191.

32 See A Fischer-Lescano and G Teubner, 'Regime-Collisions: The Vain Search for Legal Unity in the Fragmentation of Global Law (2004) 25 Michigan Journal of International Law 999.

33 The point is made also by Zetzsche, 'Die Marktsondierung' (n 19) 610, who also adds France. In particular, see points 1.4.5 and 1.4.6 G in the Code of Market Conduct containing rules on market soundings.

34 On 23 June 2016, a referendum was held in which the majority of British voters chose to leave the European Union; as a consequence, the British government triggered the exit procedure under Article 50 of the TFEU. At the moment, it is unforeseeable what the final outcome of this procedure, and of the following negotiations, will be.

35 In 2015, the largest shareholders' voting shares of companies listed at the Milan stock exchange was 29\%: F Bulfone, 'Insider job: corporate reforms and power resources in France, Italy and Spain' (2016) 14 Socio-Economic Review 16. On the analysis of corporate governance mechanisms as embedded in national-specific settings of dominant interests see R Aguilera and G Jackson 'The Cross-national Diversity of Corporate Governance: Dimensions and Determinants' (2003) 28 Academy of Management Review 447. 
of the working of market soundings in the MAR. Section 4 introduces the four situations we intend to study. Section 5 analyses the interaction between company law and market soundings in Italy and the U.K. Short conclusions are elaborated in Section 6.

\section{MARKet SOUNDings Before the Market Abuse Regulation In ITALy} AND IN THE UNITED KINGDOM

Market soundings facilitate initial public offers and secondary offers of securities. In both cases, the offer price should match a value at which most investors are ready to subscribe or buy the offered securities. In initial public offers, however, there is no market price of the issued securities that can be used as a parameter or a benchmark in establishing the issue price; in this context, the offeror needs to gauge the interests of potential investors in order to establish, according to the level of demand, the final issue price. ${ }^{36}$ By contrast, in secondary offers securities already have a market price to be used as a yardstick; nevertheless, the offering company normally tries to gauge the interest of potential investors in the offer's conditions. Furthermore, when a company aims at issuing a small amount of securities or intends to sell its own shares, public offers are excessively lengthy and timeconsuming, and companies often use a different method, commonly called 'placing' of securities or 'accelerated bookbuildings', whereby issued securities are allotted to selected investors, normally through an investment bank, in a very short period of time (normally one day). ${ }^{37}$ Furthermore, individual shareholders seeking to sell their securities might also selectively disclose inside information during an accelerated bookbuilding with the aim of gauging 'potential interest in those securities from other potential investors ${ }^{\prime 38}$ in these latter cases, the troublesome issue is finding a justification for a shareholder being in possession of inside information about the company's business. In all these circumstances, the question arises as to whether a selective dissemination of information, in order to gauge the interests of investors on the offered securities, violates rules on insider dealing. ${ }^{39}$

ABI, Encouraging Equity Investment: Facilitation of Efficient Equity Capital Raising in the UK Market (July 2013)

13.

37 See L Gullifer and J Payne, Corporate Finance Law (Bloomsbury 2016) 480.

38 See Recital 33 MAR.

39 Regarding IPOs, it is worth remembering that the prohibition of insider dealing, indeed, also applies to securities 'in respect of which a request for admission to trading on [a prescribed market] has been made'. 


\subsection{Italy}

The Italian market abuse regime is based on a dual system, which includes both criminal and administrative sanctions. ${ }^{40}$ Criminal sanctions only apply to actions committed by 'primary insiders', such as members of a company's board or other corporate bodies, or by shareholders of the issuing company; administrative sanctions apply to any person who is in possession of inside information, even if this was communicated by a primary insider. ${ }^{41}$

To understand the Italian regime, it is necessary to mention that provisions on disclosure of inside information were neither amended nor officially repealed after the MAR entered into force (July 3 2016). Before that date, the question arose of whether, and to what extent, market soundings were exempted from the application of the Italian regime on the abuse of inside information. ${ }^{42}$ In this regard, this question has exclusively arisen with regard to IPOs and share issues with a prospectus, whereas accelerated bookbuildings of listed companies do not seem to have been developed in Italy. ${ }^{43}$

First of all, even before the MAR, selective disclosures made in the 'normal exercise of an employment, a profession or duties' were not deemed unlawful disclosure of inside information. ${ }^{44}$ Additionally, issuers that disclosed inside information to third parties in the normal exercise of an

40 Legislative Decree N. 58/1998, as amended, hereinafter 'Unified Act on Finance’. On this dual system, see M Ventoruzzo, Do Market Abuse Rules Violate Human Rights? The Grande Stevens v. Italy Case (2014) ECGI Law Working Paper, available under ssrn.com.

$41 \quad$ Unified Act on Finance, Article 187-bis.

42 On selective dislosures in the 'pre-marketing' phase of an IPO see, S Lombardo Quotazione in borsa e stabilizzazione del prezzo delle az̧ioni (Giuffrè 2011) 236.

43 We take this information from Borsa Italiana, see the link at http://www.borsaitaliana.it/notizie/sottola-lente/accelerated-bookbuild-157.htm.

$44 \quad$ Unified Act on Finance, Article 184(1)(b) and Market Abuse Directive Article 3(a). See now Market Abuse Regulation Article 10, on which see C Mosca 'Article 10: Unlawful disclosure of inside information' in M Ventoruzzo and S Mock (eds.), Market Abuse Regulation: Commentary and Annoted Guide (Oxford University Press 2017), forthcoming. In Italy, due to a reform of 2005, the 'normal exercise of an employment, a profession or duties' has become an element of the crime (i.e. of the actus reus) which is to be proven by the public prosecutor, while previous rules only exempted disclosures made with a 'justified motivation' that had to be proven by the defendant: Statute n. 262/2005, 28 January 2005, L Foffani ‘Art. 184' in F Vella (ed.), Commentario T.U.F. (Giappichelli 2012) vol. 2 1778; S Giavazzi 'L'abuso di informazioni privilegiate', in G Canzio, LD Cerqua, L. Lupária (eds.), Diritto penale delle società (Cedam 2016$) 705$. 
employment, a profession or duties', faced - as they face today - a duty to simultaneously disclose the same information to the market, unless the recipient was bound by a confidentiality commitment based upon a statutory rule or a private agreement. ${ }^{45}$ Companies, therefore, were allowed to selectively disclose inside information to third parties even before the MAR entered into force, provided that two stringent conditions were met: (a) the disclosure is in the normal exercise of the company's business; (b) the recipient is bound by a confidentiality duty, be it based upon a statutory rule or upon a contract with the issuer in which the recipient explicitly enters into a confidentiality agreement (and obviously accepts to be 'wall-crossed'). ${ }^{46}$

In order to assess the scope of these defences, it was - and still is - crucial to clarify how Italian scholars and the supervisory authority have interpreted the criterion of 'normal exercise of an employment, a profession or duties'. This concept certainly includes disclosures that are essential elements of a profession, such as disclosure of information to a trading company or a law firm, and disclosures of information within a company or within a group of companies if they are aimed at drafting the group's consolidated accounts. ${ }^{47}$ Additionally, no doubts have arisen over whether inside information can be selectively disclosed to experts or financial and legal consultants, in order to gauge their opinion on a company's situation. ${ }^{48}$ Interestingly, the Italian supervisory authority has also held that issuers can also selectively disclose inside information to any subjects with whom negotiations related to commercial or financial transactions are on-going. ${ }^{49}$ Therefore, selective disclosures and

$45 \quad$ Unified Act on Finance Article 114.4 and Market Abuse Directive, Article 6.3 second sentence.

46 CONSOB Comunication DME/6027054, 28 th march 2006, paragraph 52. See, E Macrì, Informazioni privilegiate e disclosure (Giappichelli 2010) 95; S Gilotta, Trasparenza e riservatezza nella società quotata (Giuffrè 2012) 168; P Montalenti, 'Disclosure e riservatezza nei mercati finanziari: problemi aperti' (2013) Analisi giuridica dell'economia, 245, 251; G Strampelli, 'L'informazione societaria a quindici anni dal T.U.F.: profili evolutivi e problemi' (2014) 59 Rivista delle società 991, 1041.

47 Giavazzi, L'abuso (n 44) 706-707. See, however, Gilotta, Trasparenza (n 46) 167: selective disclosure is only allowed in the same circumstances in which an issuer can delay disclosing that information, namely in order to avoid a prejudice to legitimate interests of the company as specified by the CONSOB Regolamento Emittenti.

$48 \quad$ A Bartulli and M Romano, 'Sulla disciplina penale dell'insider trading (legge 17 maggio 1991, n. 157)' (1992) 19 Giurisprudenza Commerciale 660, 665 (which was related to previous rules, but is likely to be applied under the new formula).

49 CONSOB DME/6027054 28 March 2006 §52; see S Gilotta 'Art. 114' in Commentario T.U.F. (n 44)

1163. 
'market soundings' aimed at gauging the opinions of potential investors were compatible with the previous Market Abuse regime, within the limits described so far, even if no explicit provision existed..$^{50}$

\subsection{The United Kingdom}

UK insider dealing prohibition is also based upon a dual system. First, insider dealing is a criminal offence entailed in the Criminal Justice Act 1993, which requires a subjective element, or mens rea, for being punished. ${ }^{1}$ Secondly, insider dealing is also punished through an administrative offence, ${ }^{52}$ which, technically speaking, does not require mens rea. This second prong of the UK regime, however, has been recently amended through the Financial Services and Markets Act 2000 (Market Abuse) Regulations 2016. ${ }^{53}$ The 2016 regulation, in particular, has repealed sections 118 to 122 (a) from the Financial Services Market Act. ${ }^{54}$ The reason is, of course, that insider dealing is now entailed in a EU regulation having direct effect in the $\mathrm{UK}$ as a Member State of the EU, with the consequence that the former sections 118 - 122 of the Financial Services Market Act have become redundant. The logic of the reform is that the entire regulation of insider dealing, including the market sounding regime, is now governed by the directly applicable MAR, so that any market soundings will be exclusively assessed in light of the provisions of Article 11 of this Regulation.

50 The general definition of 'inside information' also includes circumstances that 'may reasonably be expected to come into existence', such as a plan for issuing new shares that has not been yet approved by the general meeting of shareholders and is only discussed informally at board level: Unified Act on Finance, Article 181/3(a), implementing Article 1 of Directive 2003/124/EC; see AF Tripodi, Informazioni privilegiate e statuto penale del mercato finanziario (Cedam 2012) 221.

$51 \quad$ Criminal Justice Act 1993, s. $52-64$.

52 Financial Services Market Act, s. 123. On the development of British rules on insider dealing, and the need to implement the first directive on this matter, see, PL Davies, 'The European Community's Directive on Insider Dealing: From Company Law to Securities Market Regulation?’ (1991) 11 Oxford Journal of Legal Studies 92.

53 The Financial Services and Markets Act 2000 (Market Abuse) Regulations 2016, Statutory Instrument 680/2016, s. 9. Ironically, this piece of legislation was approved on June 29, 2016 and entered into force on July 3, a few days after the Brexit referendum.

54 Financial Services and Markets Act 2000 (Market Abuse) Regulations 2016, s. 9(3). 
Market soundings have also attracted much attention in the UK financial market. ${ }^{55}$ In this respect, since 2005 the FSA/FCA handbook has specified which factors should be taken into account to assess whether a disclosure is made in the proper course of the exercise of [an] employment, profession or duties, ${ }^{56}$ In particular, any disclosures should be 'accompanied by the imposition of confidentiality requirements', should be 'reasonable' and, among other factors, should aim at facilitating a 'commercial, financial or investment transaction'. ${ }^{57}$ Additionally, questions arise as to whether an investor can refuse to be wall crossed and in which circumstances an investor refusing to be wall crossed can rely on the issuer's commitment to discuss a future transaction without transferring inside information. As we have noticed above, clarifying this issue was also one of the main concerns of the Market Abuse Regulation.

The FSA (now FCA) ${ }^{58}$ addressed market soundings in a final notice rendered in 2012 upon request of David Einhorn. ${ }^{59}$ David Einhorn was a portfolio manager (and sole shareholder) of a US based investment company (Greenlight Capital Inc), which held about 13\% of share capital of the British company Punch Tavern plc. Punch was going to raise its capital and issue new shares, and to this aim it entered into discussion with selected potential investors, in order to gauge their interest in subscribing those newly issued shares. While other investors accepted the receipt of inside information and signed specific non-disclosure agreements, Mr Einhorn explicitly refused to be 'wall-crossed' in any conversations related to possible transactions or operations envisaged by Punch. Mr Einhorn only agreed to have a telephone conference call with a broker, acting on behalf of Punch, under the assumption that it should be on a 'non-wall-crossed basis'. Nevertheless, during this conversation the broker made reference to a possible issue of new shares by Punch, aimed at repaying convertible bonds. Following this call, Mr Einhorn decided to sell part of Greenlight's shareholding in Punch

55 It is interesting to note that in the UK market IPOs are normally implemented through a 'bookbuilding' proceeding, which has replaced the more traditional process based on the role of an underwriter since the ' 90 . E Ferran and L C Ho, Principles of corporate finance law² (Oxford University Press 2014) 372.

$56 \quad$ FCA Handbook MAR 1.4.5. These provisions are based upon Financial Services Market Act s. 118(3) which specifies that disclosures are unlawful unless made in the proper course of the exercise of [an] employment, profession or duties.'

$57 \quad$ See FCA Handbook MAR 1.4.5.

58 In 2013 the Financial Conduct Authority (FCA), acting as UK Listing Authority as delegated by the Financial Services Market Act, replaced the former Financial Service Authority (FSA).

59 FSA, Decision Notice 12 January 2012. 
(which was hence reduced from $13.3 \%$ to $8.98 \%$ ). After the announcement of the raising of new capital, the share price fell by almost 30\%; consequently, by selling part of its investment in Punch, Mr Einhorn avoided a loss that would have been much more significant had he retained all shares. $\mathrm{Mr}$ Einhorn explicitly asked not to be wall crossed and not to receive inside information, and indeed the conversation with the broker was set on quite general and hypothetical terms. In this regard, it is worth remembering that Greenlight mainly invested in mispriced shares, and after the conversation with the broker Mr Einhorn understood that Punch's profile may not have fitted Greenlight's strategies. Eventually, Mr Einhorn also replied that he only sold 4\% of Punch's shares, which was the evidence that he was not sure that Punch was really about to issue new equity shares. The FSA rejected $\mathrm{Mr}$ Einhorn's arguments and, as a consequence, imposed on him and Greenlight a penalty for violation of insider dealing. The FSA, in particular, hold that, given Mr Einhorn's experience 'it should have been apparent to him that the information he received [...] was confidential and price sensitive' and, therefore, that it was a 'serious error' not having sought for a legal advice in this regard before selling Punch's shares, despite its explicit request of not being wall crossed. ${ }^{60}$

Therefore, according to the 'Einhorn doctrine', any investors which enter into conversations with a company on future possible transactions, such as the issue of new shares, should autonomously assess whether the information received falls within the definition of 'inside information', regardless of a formal statement that such conversations were held on a 'non-wall crossed basis'. This rigid interpretation of subjective factors aims at deterring insider dealings concealed behind the veil of 'nonwall-crossed' conversations. This decision is clearly one of the motives behind the decision to explicitly regulate market soundings in the new Market Abuse Regulation, which clarifies that the recipient of information in a market sounding proceeding should autonomously assess whether inside information was communicated or not, regardless of their request to not be wall crossed. ${ }^{61}$

60 In this regard, it is necessary to remember that under the original version of s. 123 FSMA, the FSA could decide not to impose penalties if there were 'reasonable grounds for it to be satisfied that' the person whose actions are discusses either 'believed, on reasonable grounds, that his behaviour did not fall within' the definitions of insider dealing or 'took all reasonable precautions and exercised all due diligence to avoid behaving in a way which fell within' the definition of insider dealing. Financial Services Market Act, s. A123 (2). See Gullifer and Payne, Corporate (n 37) 607. The new version of s. 123 FSMA, however, does not mention that the author should have 'believed, on reasonable grounds' that his behavior was not insider dealing.

61 Article 11.7. MAR. 


\section{MARKET SOUNDings In THE Market Abuse Regulation}

\subsection{What are market soundings?}

According to recital $32 \mathrm{MAR}$, market soundings 'are interactions between a seller of financial instruments and one or more potential investors, prior to the announcement of a transaction, in order to gauge the interest of potential investors in a possible transaction and its pricing, size and structuring'. This notion of market sounding reflects a broad spectrum of possible interactions between a seller of financial instruments and potential investors regarding an envisaged transaction. As already mentioned, such practices have been spontaneously developed in financial markets with regard to various contexts in a listed company's life. ${ }^{62}$

Usually, in all possible business situations, the interaction between a seller and potential investors prior to the formal conclusion of a deal includes preliminary contractual steps, which are aimed at aligning the different interests and at reducing informational asymmetries. ${ }^{63}$ These interactions may give rise to several critical issues related to possible exchanges of information. In order to avoid any uncertainties regarding these new commonly used practices, the Market Abuse Regulation explicitly covers market soundings. The first aim of new rules on 'market soundings' is, therefore, to clarify whether, and to what extent, such selective disclosure does not infringe general insider trading principles. Recital 32 points out that market soundings 'are a highly valuable tool to gauge the opinion of potential investors, enhance shareholder dialogue, ensure that deals run smoothly, and that the views of issuers, existing shareholders and potential new investors are aligned. They may be particularly beneficial when markets lack confidence or a relevant benchmark, or are volatile. Thus, the ability to conduct market soundings is important for the proper functioning of financial markets and market soundings should not in themselves be regarded as market abuse'.

And yet there is no real contradiction between general rules against insider trading, which focus on full disclosure of inside information in order to grant equal access to information, and

62 Recital 33 MAR provides some non-exhaustive examples of market soundings in terms of M\&A, debt issuance, capital increase, and accelerated bookbuilding.

63 One may only think of the activity of due diligence as a mechanism designed to reduce asymmetric information. 
provisions on market sounding. As is well known, insider trading in the last 60 years has been extensively debated under legal, economic, as well as law and economics perspectives. ${ }^{64}$ The most common justification underpinning prohibition of insider trading and rules on disclosure of inside information is the aim of reducing information asymmetries, which might discourage potential investors and, as a consequence, jeopardize market liquidity and efficiency as well as the dimension of the market. Market soundings, albeit involving selective disclosures of (inside) information, might be beneficial when a transaction becomes feasible after gauging potential investors' opinions. Market sounding can be useful to correctly identify the efficient price at which the transaction takes place. Regulations and, in general, institutional settings of financial markets should aim at encouraging investments and trusts, facilitating an efficient resource allocation and at allowing market prices of securities to be as efficient as possible. ${ }^{65}$ Therefore, to the extent that market soundings serve the purpose of increasing information exchanges between contractual parties, their benefits are larger than their costs and market efficiency is likely to be increased. ${ }^{66}$ To be sure, market soundings are not the only borderline situations where a tension arises between, on the one hand, full disclosure of inside information and prohibition of insider trading and, on the other hand, advantageous effects of communicating/using inside information for specific purposes. Pragmatically, EU legislation tries to strike a balance between different purposes and principles, by regulating various exceptions to its general principles. ${ }^{67}$

64 It is not possible here to provide a full overview of the literature on insider trading: see U Bhattacharya, 'Insider Trading Controversies: A Literature Review' (2014) 6 Annual Review of Financial Economics 385; see also JR Macey, Insider trading: economics, politics and policy (AEI Press 1991); SM Bainbridge, Securities law: insider trading (Foundation Press 1999). A comparison between the US and the EU legal framework can be found in M Ventoruzzo, Comparing Insider Trading in the United States and in the European Union: History and Recent Developments (2014) ECGI Law Working Paper, available under ssrn.com.

65 RJ Gilson and R Kraakmann, 'The mechanism of market efficiency' (1994) 70 Virginia Law Review 549.

66 D Zetzsche, Normaler Geschäftsgang und Verschwiegenheit als Kriterien für die Weitergabe transaktionsbezogener Insiderinformationen an Arbeitnehmer' (2015) 18 Neue Zeitschrift für Gesellschaftsrecht 817, 820; See also Lombardo, 'I sondaggi' (n 19) 160.

67 Such exceptions are: (i) delay of disclosure of inside information (Article 17.4. MAR), on which see S Gilotta, 'Disclosure in Securities Markets and the Firm's Need for Confidentiality: Theoretical Framework and Regulatory Analysis' (2012) 13 European Business Organization Law Review 45; (ii) safe-harbors regarding buy-back programmes and stabilization activity (Article 5 MAR) on which see M Simes and A De Cesari, 'The Law and Finance of Share Repurchases in Europe' (2012) 12 Journal of Corporate Law Studies 33; S Lombardo, 'The Stabilisation of the Share Price of IPOs in the 
In order to better understand market soundings, it seems useful to address the main features of the MAR. Its main purpose is ensuring equal access to inside information with the aim of facilitating an efficient working of financial markets. ${ }^{68}$ The crucial concept is 'inside information', ${ }^{69}$ namely information that (i) is precise, (ii) is not public (iii), has a direct or indirect relation with one or more issuers or financial instruments and (iv), if made public, would have a significant effect on prices of financial instruments. In particular, a piece of information is 'precise' when it (i) indicates a set of circumstances which exists or which may reasonably be expected to come into existence or an event which has occurred or which may reasonably be expected to occur and (ii) is specific enough to enable a conclusion as to the possible effect of those circumstances/events on the prices of financial instruments. ${ }^{70}$ Finally, the MAR codifies previous decisions of the European Court of Justice, ${ }^{71}$ by qualifying as inside information any intermediate steps of a decisional process, provided that they also fit into the four elements of the general definition. ${ }^{72}$

Insider dealing and unlawful disclosures of inside information are prohibited. In particular, both primary and secondary insiders must not ${ }^{73}$ (a) engage or attempt to engage in insider dealing ${ }^{74}$ (b) recommend that another person engage in insider dealing or induce another person to engage in

United States and the European Union’ (2007) 8 European Business Organization Law Review 521; D Boreiko and S Lombardo, 'Stabilisation Activity in Italian IPOs' (2011) 12 European Business Organization Law Review 437; (iii) legitimate behaviors under Article 9 MAR as previously foreseen in the recitals of MAD. Furthermore, the general prohibition of market manipulation (Article 15 MAR) knows some weakening in relation to accepted market practices (Article 13 MAR).

68 MAR recitals 1 and 24. Equal access has been recognized as a primary objective of insider trading regulation by the ECJ in the case Spector of 2009, ECJ, Spector Photo Group NV, Chris Van Raemdonck v Commissie voor het Bank-, Financie- en Assurantiewezen (CBFA), Case C-45/08, 23 December 2009, I-12073 (ECLI:EU:C:2009:806); see on the point e.g. L Klöhn, 'Ad-hoc-Publizität und Insiderverbot im neuen Marktmissbrauchsrecht' (2016) 61 Die Aktiengesellschaft 423, 424; Ventoruzzo, Comparing (n 64) 17.

69

70

Article 7.1.a. MAR.

Article 7.2. MAR.

ECJ, Marcus Geltl v Daimler AG, Case C-19/11, of 28 June 2012 (ECLI:EU:C:2012:397).

Article 7.3. MAR.

Article 14.1. MAR; on primary and secondary insiders see Article 8.4. MAR

Article 8.1. MAR. 
insider dealing ${ }^{75}$, (c) unlawfully disclose inside information, except where the disclosure is made in the normal exercise of an employment, a profession or duties. ${ }^{76}$

Additionally, in order to grant market egalitarianism and to prevent insider trading, inside information should be disclosed as soon as possible. ${ }^{77}$ Such a duty only concerns information related to an issuer (i.e. corporate information), while mere market information is excluded. ${ }^{78}$ A disclosure of inside information, however, can be delayed (including cases of protracted processes) when three conditions are met: (a) an immediate disclosure is likely to jeopardize an issuer's legitimate interest, (b) a delay of disclosure is not likely to mislead the public and (c) the issuer is able to ensure the confidentiality of that information. ${ }^{79}$

Interestingly, as we have seen above, when inside information is disclosed to selected third parties 'in the normal course of exercise of an employment, profession or duties', such information also has to be disclosed to the public, unless the recipient is bound by a duty of confidentiality based on law, regulations, articles of association or a contract. ${ }^{80}$ As we have described above, this provision was also entailed in the $\mathrm{MAD}^{81}$ and is important for understanding whether and to what extent selective disclosure of inside information is allowed (of course under the prohibition of insider dealing). ${ }^{82}$

$\begin{array}{ll}{ }_{75} & \text { Article } 8.2 . \mathrm{MAR} . \\ 76 & \text { Article 10.1. MAR. } \\ 77 & \text { Article 17 MAR. }\end{array}$

78 The difference between 'corporate information' (i.e. information directly concerning an issuer: Article 17.1. MAR) and 'market information' (i.e. information related to facts outside an issuer's activity) is sometimes unclear. In Relation to Article 6 MAD, see for Italy, E Pederzini, 'Art. 114 (Comunicazioni al pubblico)' in E Pederzini (ed.), La disciplina degli abusi di mercato, (2007) 30 Le nuove leggi civili commentate 973, 978; for Germany, M Pfüller, \ 15 Mitteilung, Veröffentlichung und Übermittlung von Insiderinformationen an das Unternehmenregister, in A Fuchs (hrsg.), Wertpapierhandelsgesetz. (C.H. Beck 2016) 601, 660.

A9 Article 17.4. MAR.
80 Article 17.8. MAR.
81 See Article 6.3. MAR.
$82 \quad$ This rule seems to be a legal transplant of Rule 100 of Regulation FD from the US (Regulation Fair Disclosure, on which see SEC, 1999, Release N. 34-42259, Selective Disclosure and Insider Trading. Proposed Rule, FD 64, 248 72590) where it has its origin in the capital market report system and not in the insider trading regulatory system; on which point, see H Fleischer, 'Investor Relations und informationelle Gleichbehandlung im Aktien-, Konzern- und 
In this regulatory system, Article 11 of MAR introduces rules on market soundings. In this context, the issuer or seller discloses information to one or more potential investors, prior to the announcement of a transaction, in order to gauge their interest in that transaction and its conditions, such as size and pricing. It is worth noting that the market sounding procedure is related to disclosures of any kind of information, regardless of whether it is 'inside information' or not. However, the procedural steps designed by the MAR are much more significant when inside information is made the object of market sounding. ${ }^{83}$

Two parties are involved in market soundings: (i) a disclosing market participant who communicates information to (ii) investors, in order to gauge their interests in a transaction. The disclosing market participant can be: (i) an issuer, (ii) a secondary offeror of a financial instrument in such quantity or quality that the transaction is distinct from ordinary trading and involves a selling method based on the prior assessment of potential interest from potential investors ${ }^{84}$ MAR places an obligation in particular on the disclosing market participant party.

Before engaging in a market sounding, the disclosing market participant has to assess whether inside information will also be involved. In this respect, disclosers should hold a written record of their conclusions and the reasons thereof, and should inform the competent authority of any market sounding procedure upon request. The framework requires this behaviour to be taken in each disclosure of information throughout the course of the market sounding. ${ }^{85}$ Provided the general prohibition of unlawful disclosure of inside information, ${ }^{86}$ the disclosing market participant can disclose inside information (a) in the normal exercise of an employment, a profession or a duty, and (b) if the recipient is bound by a confidentiality duty. In this respect, Article 11 MAR explicitly clarifies

Kapitalmarktrecht' (2009) 38 Zeitschrift für Unternehmens- und Gesellschaftsrecht 505, 516. On Regulation FD see, M Bengtzen, 'Private Investor Meetings in Public Firms: The Case for Increasing Transparency' (2017) 22 Fordham Journal of Corporate and Financial Law 33. In the US there is actually not a general provision of full disclosure comparable to Article 17 MAR in Europe (on this point, see Ventoruzzo, Comparing (n 64) 14; SEC, Regulating, 72591).

83 Recital 34 specifies that 'conducting market soundings may require disclosure to potential investors of inside information'.

$84 \quad$ A disclosing market participant can also be an emission allowance market participant or a third person acting on behalf or on account of the market sounding receiving the same level of information.

85 Article 11.3. MAR.

86 Article 10.3. MAR. 
that disclosure of inside information made in the course of a market sounding procedure is deemed to be made 'in the normal exercise of an employment, a profession or duties' ${ }^{97}$

Under the Market Abuse Directive, as we have seen above, the ECJ in the Grongaard and Bang case ${ }^{88}$ decided that a piece of information can be disclosed in the normal course of the exercise of an employment, profession or duties if (i) there is a close link between the disclosure and the exercise of the employment, profession or duties and (ii) the disclosure is strictly necessary for the exercise of that employment, profession or duties. Under the MAR, which allows and regulates market soundings, the question arises of whether the rule in the case Grongaard should continue to be applied in the new regulatory regime. Should the answer be in the positive, the consequence would be that a market sounding could only be undertaken if the disclosure is strictly necessary for implementing the envisaged transaction. ${ }^{89}$ The Market Abuse Regulation, however, follows a formal approach, by maintaining that, when the offeror complies with the procedural rules set forth in Article $11,{ }^{90}$ a selective disclosure is deemed to be made in the normal exercise of the discloser's employment, profession or duty. In other words, the satisfaction of the special procedural conditions set in Article 11 is likely to replace the requirements set forth by the ECJ in the Grongaard decision. ${ }^{11}$ This solution mirrors the British regime, in which a disclosure is deemed to be made in the exercise of the discloser's employment, profession or duties, among other factors, when it is 'reasonable' for the purpose of attaining an allowed purpose. ${ }^{92}$

The disclosing market participant that communicates inside information has to properly qualify its relationship with the person receiving the inside information. ${ }^{93}$ In short, the disclosing market participant is required to (a) obtain the consent of the person getting the market sounding to

87 MAR Article 11.4. and recital 35. See also Tissen, 'Die Investorensuche' (n 19) 1255.

$88 \quad$ ECJ, Case C-384/02, 22 November 2005.

89 See (with different opinions), Tissen, 'Die Investorensuche' (n 19) 1255; Poelzig, 'Insider-und' (n 6) 535; Zetzsche, 'Normaler' (n 66) 819; Zetzsche, 'Die Marktsondierung' (n 19) 613.

90 And, in particular, the application of Article 11.3. and 11.5. as explicitly required by Article 11.4.

91 The purpose of Article 11 MAR is to regulate market soundings that have the aim of gauging the interests of possible transactions; the scope of this rule bigger that the scope of Article 10.1 MAR. On the same result, see also Zetzsche, 'Die Marktsondierung' (n 19) 613.

92 FSA/FCA guidelines MAR 1.4.5. as amended on 3/7/2016.

93 Article 11.5. MAR. 
receive inside information, (b) inform the person getting inside information that he or she is prohibited to conduct insider trading, (c) inform the person to keep the information confidential. ${ }^{44}$ The disclosing market participant seems to be free to select the recipients of disclosed information; it is however controversial whether all recipients should receive equal treatment and the same kind of information. ${ }^{95}$ Since the ratio of the MAR is to grant equal access and market egalitarianism, one could argue that the exception to this general rule requires that those who get inside information in a market sounding obtain the same (in terms of quality and quantity) inside information, so symmetrically granting a principle of equal treatment not only at the general rule level but also at the exception level. ${ }^{96}$

\subsection{Market soundings and information}

In a market sounding procedure, the disclosing market participant can communicate pieces of information that are not deemed 'inside information'. In this case, the discloser faces simplified duties regarding the minutes and the records that are to be kept. In particular, the discloser should indicate that the recipient is about to receive information that 'the disclosing market participant considers not to be inside information ${ }^{97}$ and the recipient should consent to such disclosure on a 'non-wall-crossed' basis. ${ }^{98}$ By accepting a market sounding, however, the recipient is not automatically safe, as he should 'assess for itself whether it is in possession of inside information or when it ceases to be in possession of inside information'.99 The MAR, therefore, seems to codify the FCA Einhorn decision, where it is clearly stressed that recipients should autonomously assess whether the information received is 'inside information'.

$94 \quad$ To the extent that the delay of information according to Article 17.4 is a prerequisite to permit market soundings according to Article 17.8., the obligation of confidentiality owed by the person receiving the information has to be qualified according to national elements because the duty can be based on law, on regulations, on articles of association or on a contract.

95 Indeed, the extent to which the persons receiving the market sounding with inside information receive the same amount (in terms of quality and quantity) of information is doubtful at Level 1. At Level 2, Recital 1 and Article 3.5 of CDR 2016/960 specify that all persons receiving the market information receive the same level of information.

96 See also Zetzsche 'Die Marktsondierung' (n 19) 614.

$97 \quad$ CIR 2016/959 annex II, vi.

98 Article 11.5.1.a. MAR and Article 3.3(g) CIR 2016/960.

$99 \quad$ Article 11.7. MAR. 
In most cases, the disclosing market participant will communicate inside information and Article 11 MAR primarily regulates this situation. Within this legal framework, some questions arise in relation to market soundings and communications of inside information, which present some degree of complexity. The first issue is the relationship between communication of inside information during a market sounding and the allowed delay of information (hereunder paragraph a). Once this preliminary question is clarified, we can address other issues, namely: whether a transaction discussed during a market sounding represents inside information (hereunder paragraph b); the possibility that in a transaction that require several steps to concretize, ${ }^{100}$ the same transaction becomes at one point inside information (hereunder paragraph c); the delimitation of inside information to be communicated (hereunder paragraph d).

\section{a. $\quad$ The issuer is allowed to delay a disclosure of inside information}

As a first preliminary issue to be clarified, it is questionable whether the transmission of inside information in the context of a market sounding requires that the disclosure is being delayed according to Article 17.4 MAR. ${ }^{101}$ MAR requires full disclosure of information as an incentive to avoid insider trading, yet at the same time it allows the delaying of such disclosure in specific circumstances. As we mentioned above, a delay is justified (a) if a prompt disclosure is likely to jeopardize legitimate interests of the issuer, (b) if a delay of disclosure is not likely to misled the public and (c) if the issuer is able to ensure the confidentiality of that information. In this context, it appears that the communication of inside information in the context of a market sounding can legitimately be done only when a delay of disclosure is justified under Article 17.5 MAR.

\section{b. The envisaged transaction is inside information}

The operation disclosed in a market sounding is to be considered inside information when its realisation is almost certain. In this case, the envisaged transaction fulfils all four elements of the

$100 \quad$ Article 7.2. and 7.3. MAR.

101 The relation between market soundings and delay of information according to Article 17.4. MAR is also made by Di Noia, Milic and Spatola 'Issuers' (n 6) 102; Lombardo 'I sondaggi' (n 19) 163; Zetzsche 'Die Marktsondierung' (n 19) 613. ESMA does not explicitly consider the relation between market soundings and delay of information in its guidelines. Indeed, ESMA does not directly specify that the transactions in which market soundings are conducted could justify delay. There is an indirect reference to delay of information in the context of a market sounding only in ESMA/2014/809, 23 nr. 74. 
definition of inside information and, as a consequence, it should be disclosed to the market. ${ }^{102} \mathrm{~A}$ typical example is the situation when directors of a listed company have reached an agreement on a capital increase, but have not yet taken an official decision. In this case, the issuing company has an interest in capturing the opinion of potential investors on this transaction's conditions. In such a situation, information on an imminent secondary offering of securities is to be classified as 'inside information', which the issuer should immediately disclose to the market. In this scenario, any selective communication of the plan of issuing shares risks violating the prohibition of 'insider trading'. As mentioned in point (a), the disclosure of inside information about a capital increase through a secondary offering is delayed and the market sounding communicates to selected investors the inside information about the increase of capital.

\section{c. The envisaged transaction is the outcome of many intermediate steps}

Contrary to the case discussed in point (b), in which a transaction has been already decided and is deemed inside information, other transactions might require several steps to be eventually decided. Therefore, the question arises of when such an operation becomes sufficiently certain to be treated as inside information. A typical example is the situation when executive directors aim at increasing their company's capital, and in order to reach this goal they need to convince other directors and a majority of shareholders, since such a decision requires the intervention of both the board of directors and the general meeting of shareholders. In that case, executive directors inform selected large shareholders of a possible capital increase, in order to gauge their opinion and their availability to vote in favour of this proposal and, eventually, to subscribe new shares. This communication does not involve a disclosure of inside information, since this capital increase also depends on what the recipient shareholders are going to decide on its merit and, therefore, it is far from being certain at the

102 This seems to be the case realized in the Harrison case decided by the FSA in September 2008. Mr Harrison, an investment manager, was informed about the imminent refining of Rhodia SA in a kind of market sounding and used this inside information (disclosed later on) to trade on it. Mr Harrison was informed about the operation in a kind of market sounding: 'Credit Suisse contacted Mr Harrison in order to help establish the correct pricing and other feedback on the specifics of the proposed refinancing which involved the tender for certain of its existing bonds and the issue of new floating rate notes. This necessitated providing Mr Harrison with inside information regarding the proposed refinancing', see FSA, 2008, Final Notice, available under https://www.fca.org.uk/publication/finalnotices/steven_harrison.pdf, 2.2.1. 
moment of its disclosure. ${ }^{103}$ To avoid that shareholders who were sounded out speculate on the basis of this information, as soon as a capital increase becomes reasonably certain (for instance because most shareholders have positively reacted to a proposal) it is to be deemed inside information that should be disclosed to the market. ${ }^{104}$

In this context, the question arises as to whether the fact that a person uses his or her own knowledge on how he or she will behave regarding a certain market transaction should be deemed inside information. In our case, shareholders who were sounded out could speculate by using their knowledge on their own decisions. ${ }^{105}$ This question does not seem to be yet fully clarified, albeit the MAR seems to answer in the negative, by maintaining that 'the mere fact that a person uses its own knowledge that it has decided to acquire or dispose of financial instruments in the acquisition or disposal of those financial instruments shall not of itself constitute use of inside information'. ${ }^{106}$

What matters for the purposes of this article is that recipients of market soundings should assess by themselves whether they are in possession of inside information or when they cease being in possession of inside information. ${ }^{107}$ This is a catch-all provision that puts a precise obligation on

103 This kind of information about a possible increase in capital could be qualified as a light information in terms of the proposal of the European Commission where the information is not precise but of potential interest for a reasonable investor.

104 This argument has already been proposed in Lombardo, 'I sondaggi' (n 19) 163. Apparently, ESMA does not consider this hypothesis but recital 1 of CIR 2016/959 considers the possibility that the nature of information changes after the market sounding.

105 In the example, the shareholders are sounded out according to Article 11 and contribute to create and possess the inside information as persons '(b) having a holding in the capital of the issuer' according to Article 8.4(b) MAR. This issue has been of particular relevance regarding takeover regulation. In Italy, see the three decisions issued in the 'Cremonini' case (on files of the authors): on the one hand the Administrative Tribunal ('TAR') of Lazio held that when somebody uses his or her own knowledge on how he or she will behave regarding a certain market transaction is not to be deemed as inside information, on the other hand, the Court of Appeal Bologna and the Tribunal of Milan followed the opposite theory, and maintained that such a situation is to be assessed as use of inside information. For a discussion of this topic, see S Lombardo, 'OPA, informazione privilegiata e insider di se stessi' (2013) 32 Le Società 50 (for Italy) and P.R. Mennicke, $\int 14$ Verbot von Insidergeschäften, in A Fuchs (hrsg.), Wertpapierhandelsgesetz. (C.H. Beck 2016) 472 , 496 (for Germany).

106 Article 9.5. MAR.


persons receiving a market sounding. ${ }^{108}$ This provision is crucial for addressing market operations requiring several steps and for clarifying whether a piece of information becomes inside information due to an active involvement of the sounded party. The catch-all rationale of this provision is modelled on the basis of the British Einhorn doctrine: as we have seen above, ${ }^{109}$ according to this doctrine any investor which enters into conversations with a company on future possible transactions, such as the issue of new shares, should autonomously assess whether the information received falls within the definition of 'inside information', regardless of a formal statement that such conversations were held on a 'non wall crossed basis'.

\section{d. Disclosure of many pieces of inside information}

When potential investors are sounded out regarding an envisaged transaction, several different pieces of inside information may be disclosed by the issuer or seller. In these cases, it is to be assessed whether each piece of information falls within the scope of Article 11 MAR or not. Such assessment is to be conducted on a case-by-case basis, so that no comprehensive taxonomy seems to be feasible. ${ }^{110}$ In this regard, when the disclosed information is related to the envisaged transaction, such disclosure

108 This is the case although in the market sounding regulatory framework duties are mostly allocated on disclosing market participants. Note that the Article starts with the words 'Notwithstanding the provisions of this Article, ...': which means that the requirement of this provision does not only refer to Article 10.5 MAR but to the entire Article. On the importance of Article 11.7. MAR, see also Zetzsche, 'Die Marktsondierung' (n 19) 618.

Article 11.7. MAR seems to replicate the content of Article 8.4. last sentence, which provided the general principle that 'This Article also applies to any person who possesses inside information under circumstances other than those referred to in the first subparagraph where that person knows or ought to know that it is inside information'.

$109 \quad$ See n 59 ad accompanying text.

110 ESMA recognizes the nature of the problem in ESMA/2014/809, 23 Nr. 74: 'The DMP should determine what information it intends (and is appropriate) to disclose to potential investors over the course of a sounding. Generally, this will be information related to the exact characteristics of the possible transaction in relation to which it intends to sound out investors. However, it may also include other information not necessarily directly related to the possible transaction but providing important context to the transaction. Information disclosed by a DMP should enable a potential investor to make a sufficiently informed assessment. So, for example general information about the issuer such as its financial standing could be useful. However, it should be noted that any inside information about the financial standing of the issuer should have been made public by the issuer, unless delayed disclosure is justified. At the same time, the DMP should avoid disclosing additional inside information that is not useful'. On this particular point see also Zetzsche, 'Die Marktsondierung' (n 19) 619. 
falls within the scope of Article $11 \mathrm{MAR}$, while in any other cases it is to be treated as an unlawful disclosure of inside information. ${ }^{111}$

\section{MARKET SOUNDINGS IN FOUR SITUATIONS}

As we have mentioned above, this article assesses four situations in which market soundings can be carried out by disclosing inside information. For explanatory purposes, the main characteristics of such four situations will be described hereunder.

\section{a. Initial Public Offerings (IPO)}

Initial public offerings normally lead a company to list its shares on a regulated market. ${ }^{112}$ An IPO includes two distinct, albeit interrelated, operations: (a) the company (and/or its shareholders) offers shares to the market in the guise of a public offering and (b) the company is admitted to trading on a regulated market. Until an IPO is fulfilled, the issuing company is not listed on a regulated market and its shares are not yet widely held among investors. European law regulates the prospectus that the offering company has to publish, setting uniform rules on information disclosure, ${ }^{113}$ while other legal aspects that govern the offering (in particular company law issues and the contractual law aspects,

111 See ESMA/2014/809, 23 Nr. 74; Zetzsche, 'Die Marktsondierung' (n 19) 619.

112 To be sure, the IPO could also be done on a non-regulated market but we limit ourselves to the study of the regulated market case. Indeed, the IPO is not limited to the regulated market but can be done also on an alternative trading system (a multilateral trading facility, MTS). The scope of MAD was limited to regulated markets (Article 9: the Directive applies to a financial instrument admitted to trading on a regulated market in at least one Member State, or for which a request for admission to trading on such a market has been made, irrespective of whether or not the transaction itself actually takes place on that market) while the scope of MAR has been extended to cover also among others multilateral trading facility (MTS) (Article 2.1.b) MAR: financial instruments traded on an MTF, admitted to trading on an MTF or for which a request for admission to trading on an MTF has been made).

113 Directive 2003/71/EC of the European Parliament and of the Council of 4 November 2003 on the prospectus to be published when securities are offered to the public or admitted to trading and amending Directive 2001/34/EC, OJ 31.12.2003, L 345/64, as later supplemented by Commission Regulation (CE) No 809/2004 implementing Directive 2003/71/EC of the European Parliament and of the Council as regards information contained in prospectuses as well as the format, incorporation by reference and publication of such prospectuses and dissemination of advertisements, OJ 30.04.2004, L 149/1, and now replaced by the Prospectus Regulation (n 9). 
including liability issues) are almost entirely in the hands of Member States. ${ }^{114}$ IPO procedures are shaped according to international practical standards that have been developed on the basis of US and European tradition, so that IPOs present common features in most Member States.

In this regard, it is worth mentioning that IPOs are often structured as the combination of a public offer addressed to domestic retail investors and one or more tranches, which are often directed to international institutional investors. ${ }^{115}$ In such 'placement tranches' syndicate banks are usually free to allot the offered securities around the world, provided that they have obtained all necessary licenses. ${ }^{116}$ In this regard, a fundamental decision that the issuing company should take is whether it should also offer securities to the U.S. market, in the guise of either a global offer or a private placement, by respecting U.S. securities regulation. ${ }^{117}$ The division into a retail offer and one or more global tranches raises the question as to whether disclosed information can differentiated across different tranches, with the consequence of not treating potential investors equally. ${ }^{118}$ Additionally,

114 Concerning the issue of prospectus liability, see the comparative analysis of the different contributions related to the different Member States, in KJ Hopt and H-C Voigt (eds.), Prospekt- und Kapitalmarktinformationshaftung (Mohr Siebeck 2005); See also, ESMA, Report. Comparison of liability regimes in Member States in relation to Prospectus Directive, 30 May $2013,2013 / 619$

115 Different combinations of domestic public offers and international offers are described in R Geddes, IPOs and equity offerings (Elsevier Science 2003) 50-53.

116 See, P Espinasse, IPO: A Global Guide (Hong Kong University Press 2011) 125.

Italian companies are used to structure IPOs as a combination of a retail offer with an institutional tranche for U.S. institutional investors. On Italian companies that decide to go public: Lombardo, Quotazione (n 42) 244; D Boreiko and S Lombardo, 'Italian IPOs: Allocations and Claw Back Clauses' (2011) 21 Journal of International Financial Markets, Institutions and Money 127; P Giudici and S Lombardo, 'La tutela degli investitori nelle IPO con prezzo di vendita aperto’ (2012) 57 Rivista delle Società 907; P Giudici, L’appello al pubblico risparmio e i contratti degli emittenti: IPO; contratto di collocamento; prospetto, in V Roppo and AM Benedetti (eds.), Trattato dei contratti (Giuffrè 2014) 965; P Giudici, Le offerte degli emittenti: determinazione dei prezii e altre clausole contrattuali. I contratti con i gatekeepers, V Roppo and AM Benedetti (eds.), Trattato dei contratti (Giuffrè 2014) 991. Such a uniform pattern seems to be less common for British companies (probably because they rely on a highly sophisticated and liquid domestic market), see C Caglio, K W Hanley and J Marietta-Westberg, 'Going public abroad' (2016) 41 Journal of Corporate Finance 103.

117 Offers of securities are to be made under Regulation S, while private placements for US institutional investors follow Rule 144 Securities Act.

$118 \quad$ Ferran and Ho, Principles (n 55) 416. 
public offers addressed to retail investors raise the question of whether discriminatory treatments of potential investors are allowed.

After a first contact between the originating investment bank and the company to plan the IPO, the issuing company files a request to be admitted to trading with a regulated market; at the same time a premarketing activity is run. The IPO's prospectus is published after authorization of the competent authority and the public offering is run. Before the prospectus is published, however, the investment bank sounds out potential institutional investors to gauge their interest in the issuing company and to establish a price range (bookbuilding procedure). ${ }^{119}$ This premarketing activity is commonly undertaken after the issuing company applies for admission to trading on a regulated market and, therefore, it falls within the scope of insider trading rules. ${ }^{120}$

Premarketing activities raise the issue of which information can be disclosed to potential investors and how such disclosure is to be coordinated with the prospectus. The main point is that, in order to grant equal treatment of all investors, the quality and quantity of information disseminated to potential institutional investors should be coherent with the content of a prospectus which is about to published. ${ }^{121}$ Therefore, the Market Abuse Regulation (and before it entered into force, the Market Abuse Directive) and the Prospectus Directive (replaced now by the Prospectus Regulation) are to be conceived as a continuum aiming at protecting market integrity and price discovery mechanism. ${ }^{122}$ The MAR does not change this regulatory scheme and increases the possibility for market soundings to be done in a way that is more protective of the interests involved. After filing for admission to trading, and before the prospectus is published, market soundings between the investment bank and/or the company to test the potential interest of institutional investors in order to set the price range to be

$119 \quad$ Ferran and Ho, Principles (n 55) 371 - 372; Gullifer and Payne, Corporate (n 37) 480.

$120 \quad$ Article 2.1(a) MAR.

121 In Italy, such continuity between MAD and prospectus in terms of disclosure to all the involved investors is granted by CONSOB' regulation on issuers (Regolamento Emittenti). Article 34-decies CONSOB regulation on issuers regulated the phase before the publication of the prospectus providing that the diffusion of news, market soundings and collections of non-binding orders was possible, provided that: (a) disclosed information is coherent with those contained in the prospectus, (b) the relative documentation is transmitted to CONSOB, (c) express reference that the prospectus will be published is made, and (d) it should be mentioned that any intention to buy is non held as a binding offer. Article 34-sexies ensures the coherence between the information disclosed in the prospectus (for the retail offering and for the institutional offering) and after the publication of the prospectus.

122 See Giudici and Lombardo, 'La tutela' (n 116) 932 n 77. 
published in the prospectus, should be complemented through the procedure laid down in Article 11.3 MAR, granting a better implementation of the transparency and correctness of the price discovery mechanism. ${ }^{123}$ Furthermore, we note that the new regime seems not to legitimate a different treatment among institutional investors. In other words, MAR does not provide to the investment bank and/or the company the possibility to discriminate among institutional investors in disseminating different types and degrees of inside information according to the necessity of the case. ${ }^{124}$ To be sure, the market sounding mechanism cannot be used after a prospectus has been published (i.e. during the offering); the reason is that the prospectus regime, which aims at protecting the integrity of the offering (and of the price formation mechanism if there is an open price system), ${ }^{125}$ provides for a duty of equal treatment of all investors regarding the possibility to obtain information.

\section{b. Secondary offerings}

Market soundings may occur for secondary offerings (or seasoned offerings), when an already listed company seeks to increase its capital. In this transaction, securities regulation and company law are strictly intertwined, and such a connection raises several problems with respect to market soundings, as we shall see hereunder.

\section{c. Accelerated bookbuilding when the offeror is the company}

Recital 33 MAR describes a case of accelerated boobuilding as follows: "where the sell-side analyst is seeking to sell a large amount of securities on behalf of an investor and seeks to gauge potential interest in those securities from other potential investors'. Article 11.1 MAR clarifies this description by stating that a market sounding is made by secondary offerors of a financial instrument, when the offer is 'in such quantity or value that the transaction is distinct from ordinary trading and

The MAR is applied and enforced extraterritorially, see Article 2.4 MAR: 'The prohibitions and requirements in this Regulation shall apply to actions and omissions, in the Union and in a third country, concerning the instruments referred to in paragraphs 1 and 2'. See also, Zetzsche, Marktintegrität/Marktmissbrauchsrecht (n 6) 185, at para 43. As a consequence, the MAR also applies to institutional offerings directed to U.S. institutional investors under Regulation S, Rule 144A Securities Act.

124 On this point see CDER 2016/960 Recital 1 and Article 3.5 that require respectively 'all the persons receiving the market sounding receive the same level of information' and the 'disclosing market participant shall ensure that the same level of information is communicated to each person receiving the market sounding in relation to the same market sounding'.

125 Article 8 of the Prospectus Directive (now Article 17 Prospectus Regulation). 
involves a selling method based on the prior assessment of potential interest from potential investors' ${ }^{126}$ A company that holds own shares as treasury shares ${ }^{127}$ or seeks to issue new shares, might implement an accelerated bookbuilding in order to quickly allot such shares among selected investors.

In a typical accelerated bookbuilding, the selling party asks an investment bank to find potential investors for the shares at a selling price defined by testing the potential interest of the investors. ${ }^{128}$ The reason for using this mechanism is that the offering on the market of a consistent amount of shares usually depresses the price of the shares. Ideally, the equilibrium price of an accelerated bookbuilding is lower than the listing price but higher than the price that would be reached by a selling on the market because of the depressing consequence of the large amount of offered shares. ${ }^{129}$

In order to analyze the situation in which a company tries to sell its own shares by way of an accelerated bookbuilding it is useful to briefly analyze the opposite situation, i.e. when the company tries to buy its own shares. Note that in this case, according to the ratio of MAR, a listed company

126 To be sure, we note that the Italian text is different from the English, German and French text with respect to the explicit reference to the secondary market as opposed to the secondary offeror which could be understood as opposed to the issuer of letter (a): (b) un offerente sul mercato secondario di uno strumento finanziario, (b) a secondary offeror of a financial instrument, (b) einen Zweitanbieter eines Finanzinstrumen, (b) par un offreur secondaire d'un instrument financie. Zetzsche (Marktintegrität/Marktmissbrauchsrecht (n 6), at para 217b, describes the situation of a block trade in which a large amount of shares are placed outside of any regulated market; such a transaction (which amount to about $0.5 \%$ of the total shares) can have a negative impact upon market liquidity. Block trades are types of accelerated secondary offerings: B Bortolotti, W Megginson and SB Smart, 'The Rise of Accelerated Seasoned Equity Underwritings' (2008) 20 Journal of Applied Corporate Finance 35, 37.

127 The second company law Directive allows issuers to hold their own shares as treasury shares but only up to a certain limit in order to avoid problems with the regime of capital and capital maintenance which is a core element of European company law. See in particular, Article 22 et seq. of Directive 2012/30/EU of the European Parliament and of the Council of 25 October 2012 on coordination of safeguards which, for the protection of the interests of members and others, are required by Member States of companies within the meaning of the second paragraph of Article 54 of the Treaty on the Functioning of the European Union, in respect to the formation of public limited liability companies and the maintenance and alteration of their capital, with a view to making such safeguards equivalent, OJ L 315, 14.11.2012, $\mathrm{L} 315 / 74$.

128 On accelerated bookbuilding offerings (ABO) see Bortolotti, Megginson and Smart, (n 126), passim.

129 The final price depends on several variables related e.g. to liquidity of the shares, amount sold, ability of the investment bank etc. 
cannot acquire its own shares on the free market (Article 14 MAR) unless any pieces of inside information have been published according to Article 17 MAR. In other words, with regard to treasury shares listed companies are subject to MAR as any other investors.

One can possibly argue that no equivalence exists between an offer of shares and share repurchases, since shareholders are residual claimers and share value comprehends non-disclosed information. On the other hand, such a criticism would not take into consideration the public good character of information and the integrity of the capital market as a whole.

As in a situation where the listed company tries to buy its own shares, an accelerated bookbuilding undertaken by the company in order to sell its own treasury shares or newly issued shares raises several questions related not only to the disclosure of inside information but also the equal treatment of shareholders, and whether such a deal has to be deemed inside information to be disclosed to the market according to Article 17 MAR. ${ }^{130}$ Additionally, an accelerated bookbuilding undertaken by a company to sell its own treasury shares is to be differentiated from an accelerated bookbuilding undertaken by a shareholder to sell his or her shares in a listed company: while in the former the company has a duty to disclose the corporate information about the deal (i.e. the accelerated bookbuilding) in the latter case the shareholder does not have such a duty (unless it is a listed company) but the effectiveness of the deal is subject to full disclosure by the company because of the insider trading prohibition. ${ }^{131}$

From a functional perspective, an accelerated bookbuilding by the listed company selling its treasury or new shares can be considered as an alternative to two possible other strategies the same company can follow to sell its shares, namely (a) selling of shares on a regulated market, ${ }^{132}$ or (b) public offering of securities. The regulation of these alternative strategies is based on general principles of

130 In the first case when the company is planning the accelerated bookbuilding, the company could invoke the application of Article 17.4. delaying the disclosure of this inside information (which can be accounted as a deal like the one described in point 8.a of the ESMA, MAR Guidelines. Delay in the disclosure of inside information, 20/10/2016|ESMA/2016/1478 EN. After the accelerated bookbuilding is conducted, the application of this delay is more problematic because the deal has already been finalized and the market should be informed, as in any other deals.

131 As a result, there are two types of inside information: the inside information communicated in the market sounding and the inside information about the deal.

132 With the inconvenience of depressing the price of the shares. 
full disclosure, by way of a duty to publish a prospectus, and equal treatment of shareholders. ${ }^{133}$ The question arises as to whether the same principles have to be applied to the accelerated bookbuilding case. In other words, it is necessary to analyze whether alternative (a), which is possible only with full disclosure of inside information (because of the limit of Article 14 MAR for the company), and alternative (b), which requires the publication of the prospectus with full disclosure of information, can be replaced by an accelerated bookbuilding with the disclosure of inside information to selected institutional investors and the full disclosure of the inside information to the market before the effectiveness of the deal. Furthermore, we should also analyze whether a decided accelerated bookbuilding is to be deemed inside information to be disclosed by the issuing company according to Article 17 MAR.

Turning our attention to domestic company law rules protecting shareholders from unfair or discriminatory treatment, the MAR provides that the issuing company can proceed to an accelerated bookbuilding (both for treasury and new shares) and disclose inside information through a market sounding. The question arises as to whether these provisions are compatible with national company law rules. Contrary to alternatives (a) and (b) which require both ex ante full disclosure of inside information, the accelerated bookbuilding mechanism can be an efficient and fast instrument to collect financial resources. ${ }^{134}$ We would like to stress again that, according to the MAR, the deal can be closed only after any piece of inside information is fully disclosed according to Article 17 MAR. ${ }^{135}$

Eventually, we should address disclosure of the corporate information related to (i) a planned deal and (ii) a realized deal (Article 17 MAR). While in case (i) disclosure can be delayed, ${ }^{136}$ in case (ii) disclosure is mandatory and cannot be delayed. ${ }^{137}$

133 With its costs in terms of timing.

$134 \quad$ As in the case of accelerated bookbuilding made by a shareholder, the potential buying party becomes a person having inside information in order to equilibrate the informational asymmetry and increase the efficiency of the pricing.

135 On this point see also Zetzsche, 'Die Marktsondierung' (n 19) 619.

$136 \quad$ See $\mathrm{n} 79$ and accompanying text.

137 This means that the conditions of Article 17.4. MAR in case of an already realized operation are less present and delay is not really justifiable. In this case the disclosure of the price at which the deal has been realized could signal to the market that pieces of inside information are included in the price; this signaling would work as a mechanism to align the evaluation of the non-disclosed information acquired by the buying party with the one of the market. Imagine 


\section{d. Accelerated bookbuilding when the offeror is a shareholder}

Investment banks can also be entrusted with the task to find potential investors by shareholders who aim at selling their shares in a listed company. In this situation, it is quite natural that the investment bank sounds out potential investors, and yet it is quite unclear whether it can also disclose inside information related to the issuing company. It needs to be clarified why a selling shareholder possesses inside information related to the issuing company and whether it is allowed to disclose such information to third parties, despite the issuing company facing a duty to disclose this inside information according to Article 17 MAR.

Selling shareholders can acquire information about their company either on the basis of their holding capital of the issuing company ${ }^{138}$ or because of their being members of corporate bodies. ${ }^{139} \mathrm{~A}$ selling shareholder should comply with general rules of the insider trading regime (Article 14 MAR), unless it triggers a market sounding procedure under Article 11 MAR.

The communication of inside information between the selling shareholder and the potential investor(s) aims at balancing information asymmetry and increases the deal's efficiency. ${ }^{140}$ The selling shareholder communicates to the potential buying party inside information about the issuing company in order to establish the most efficient price, which includes this inside information. Of course, this

for instance the following situation: the listed company owns 5\% of its capital and does not disclose negative information (for one reason or another according to Article 17.4. MAR). The company needs financial resources quickly and makes an accelerated bookbuilding with a market sounding communicating to the buying party this negative inside information. The buying party discounts the negative information and the two parties reach an efficient price. In order to have effectiveness of the deal the company has an obligation to disclose the negative inside information (Article 17 MAR) because it is a piece of corporate information. Then the company also has to disclose the deal and the price at which the deal has occurred. If the price is substantially lower than the current market price (i.e. a price that is not only lower because it is an accelareted bookbuiling, e.g. $-5 \%$ but because it incorporates inside bad information, e.g. $-12 \%$ ) the market would align the evaluation of the bad inside information done by the acquiring shareholder(s) with its proper evaluation. We are not aware of any academic contributions dealing with this topic.

138 Article 8.4.b. MAR.

139 Article 8.4.a MAR.

140 Meaning in terms of asymmetric information that the potential buyer would discount the asymmetric information problem offering a lower price or that the deal would not occur. The rebalancing of the information allows the two parties to reach a price that is efficient, meaning a price that fully incorporates information and approaches the price the free market would have reached. 
inside information is not communicated to the market but serves only to equilibrate the relationship between selling party and buying party. The possible alternatives for the two parties are as follows. The selling shareholder cannot sell the shares on the market (Article 8 MAR) without previous disclosure of this inside information by the issuing company (Article $17 \mathrm{MAR}$ ): otherwise he or she would abuse this inside information the market is not informed about. On the other hand, the buying party could buy on the market in a given time framework the same amount of shares but with the danger of increasing the price.

Given this picture, the accelerated bookbuinding procedure with transmission of inside information from the selling shareholder to the acquiring shareholder(s) aims at balancing the information status about the issuing company of the two parties in relation to their specific deal so that the efficiency of the deal is increased. ${ }^{141}$ Nevertheless, the general prohibition of insider trading set by MAR impedes the effective conclusion of the deal before the listed company publicly informs the market about the inside information. ${ }^{142}$ In this case, the company is the only subject which legitimately has the obligation/right to disclose the inside information transmitted by the selling

141 During the negotiations about the planned accelerated bookbuilding between a selling shareholder and potential institutional investors with the transmission of inside information, the information status of the market is not touched: the market was not informed (of the inside information) with the old selling shareholder and (continues to be) not informed with the new potential acquiring shareholder. In other words, during the negotiations the market remains neutral to this not communicate inside information. The two contracting parties bear the risk of assessing the quality of this inside information in terms of its pricing, which could be different from the assessment of the market when the information is made public. In other words, the selling party and the buying party could legitimately think that the inside information is positive for the issuing company so increasing the price when made public (so that their evaluation discounts this good news for instance vt $10 \%$, i.e. $€ 10$, bringing their deal to a price of 110 instead of $€ 100$, i.e. the market price) while the market, when the inside information is disclosed, thinks the news is bad and brings the share price to $€ 90$.On the other hand, the selling party and the buying party could legitimately think that the inside information is negative for the issuing company so decreasing the price when made public (so that their evaluation discounts this bad news for instance by $10 \%$, i.e. $€ 10$ bringing their deal to a price of 90 instead of $€ 100$, i.e. the market price) while the market, when the inside information, is disclosed thinks the news is good and brings the share price to $€ 110$. In both cases the effectiveness of the deal is subject to full disclosure of the inside information to the market because of Article 17 MAR.

142 On the point see also Zetzsche, 'Die Marktsondierung' (n 19) 619 who relates to the German version of Recital 33 MAR where the selling side is providing to the buying side all the information to get 'die verbindliche Zusage für die Beteiligung an dem Geschäft'. The Italian text refers to 'un impegno', the English text refers to 'a financial commitment' while the French text refers to 'un engagement financier' 
shareholder to the potential acquiring shareholder(s) in order to make the deal between the two parties effective. To be sure, if the company refuses to disclose the inside information invoking the delay according to Article 17.5. MAR, the deal cannot occur. As a result, the conclusion is that the hypothesis described in Article 11.1.b. requires the previous disclosure by the listed company of the inside information communicated by the secondary offeror to potential investors to make the deal effective.

\section{MARKET SOUNDINGS AND NATIONAL COMPANY LAW REGIMES}

From a 'company law' standpoint, market sounding raises quite different problems, whose solutions, as we shall see, may not be entirely compatible with the financial regulation logic of the procedure provided by the MAR. To understand these issues, we should distinguish activities undertaken by the issuing company, either before an initial public offer or before a secondary offer of securities, from activities undertaken by a company's shareholder when he or decides to sell his or her shares.

Before initial public offers, directors, managers, or other companies' fiduciaries sound out the market by meeting selected investors to gauge their interest in subscribing newly issued securities or treasury shares and their view on such transactions. As we have seen in the previous section, when directors engage in market sounding, information is disseminated to selected potential investors, be they shareholders or not. When the company, or a company's agent, decides to sound out selected shareholders, the question arises as to whether shareholders can be discriminated according to their sophistication or the quantity of shares owned. By contrast, when third parties are sounded out, the question arises as to whether a company can disclose inside information to third parties in order to facilitate share acquisitions. The answer to both questions also depend on directors' fiduciary duties vis-à-vis their company and/or shareholders and on general conceptions regarding shareholders' position in the company. These answers, therefore, ultimately depend on company law rules, which vary across jurisdictions. By contrast, pre-marketing activities undertaken by a shareholder who seeks to sell his or her shares in the market do not involve directors' relation with shareholders or the question of whether and under which circumstances discriminations may be justified, and yet other 'company law' questions may arise. First of all, it is important to clarify whether shareholders owe each other duties of fair or equal treatment; secondly, the question arises as to whether their company can or should cooperate with them by facilitating a disclosure of inside information. 
Despite capital markets being increasingly globalized, most rules governing intra-corporate affairs, such as the relations between directors and shareholders and relations among shareholders, are nation-based and depend on a country's company law heritage. The consequence is, or could be, that national regimes may have an impact even on uniform rules such as those provided in the MAR. In this regard, it is worth remembering that inside information can be disclosed in the normal exercise of an employment, profession or duty', provided that the recipients owe a duty of confidentiality. Similarly, when an issuer discloses inside information to selected parties, 'in the normal course of the exercise of an employment, profession or duties', it must make complete and effective public disclosure of that information, unless the recipient owes a duty of confidentiality. ${ }^{143}$ The concept of 'normal exercise of an employment, profession and duty' is based, among other things, upon domestic company law rules that govern a certain issuer; ${ }^{144}$ additionally, whether and in which circumstances a recipient is validly bound through a confidentiality duty, be it based upon contract or law, also depends on national rules and principles. Therefore, directors should assess whether domestic company law rules allow such discriminatory activities and in which circumstances.

In general, we can expect that company law rules generally prohibit directors from discriminating between shareholders. The main reason is that directors' powers, however constructed, derive from shareholders' positions as 'owners', 'partners' or investors (according to the specific conception of shareholders' role that a certain legal system may want to adopt). ${ }^{145}$ Therefore, directors can never behave arbitrarily vis-à-vis their shareholders, and even if discriminations are allowed, it is reasonable to expect that the applicable company law regime requires such discrimination being supported by specific justifications for the benefit of the company as a whole, and yet the precise contours of these limits on directors' powers may vary across jurisdictions. It is worth mentioning that EU law does not impose a duty of equal treatment of shareholders. The European Court of Justice, in the case Audiolux, argued that the principle of equal treatment of shareholders who are in the same position is not a general principle of EU law; ${ }^{146}$ additionally, according to Advocat General Trstenjak,

143 Article 17.8. MAR.

$144 \quad$ C-384/02, Grongaard and Bang (n 28) 48.

145 For an overview of different constructions of shareholders' positions in the company see, M Siems, Convergence in Shareholder Law (Cambridge 2008) 60.

146 C-108/08, Audiolux SA v Groupe Bruxelles Lambert SA (GBL), 15 October 2009, I-09823 (ECLI:EU:C:2009:626), on which see FM Mucciarelli, 'Equal treatment of shareholders and European Union law’ (2010) 
in the case Commission v Spain discussing pre-emption rights granted to holders of bonds convertible to shares, the principle of equal treatment of shareholders, 'is not construed as an obligation on the part of the company to treat shareholders in the same way, but is understood to mean that unequal treatment needs sufficiently objective justification' ${ }^{147}$ Similarly, the question of whether shareholders owe reciprocal duties of 'fairness' even when they act as individuals (such as in secondary offers) are also governed by national company law rules that vary from country to country. In the next pages, we will address director duties in Italy and the U.K., in order to assess whether these national company law regimes could block market soundings or affect their feasibility.

\subsection{Italy}

Before deciding a capital increase, companies normally need to gauge the interests and the opinions of potential investors, including current shareholders, on quantity and price of newly issued shares. When shareholders' preemption rights are not limited or excluded and shares are allotted to existing shareholders, directors may want to gauge their opinion of such a transaction before calling the general meeting that should decide on its merits. Most importantly, when shareholders' preemption rights are excluded, directors need to gauge the opinion of potential investors before finalizing a proposal to be submitted to the general meeting of shareholders. The need to sound out the opinion of potential investors clearly arises when a listed company decides to issue new shares to the public. The same need, additionally, exists when new shares are allotted to selected investors through an accelerated 'bookbuilding' procedure. In this regard, it is worth stressing that Italian listed companies have not made use so far of accelerated bookbuilding to sell treasury shares or allot new shares, and yet we cannot exclude the idea that companies might be interested, in the near future, to follow such procedure, which is largely employed in sophisticated capital markets. Italian company

7 European Company and Financial Law Review 158. See also C-174/12 Alfred Hirmann v Immofinanz. AG, 19. December 2013 (ECLI:EU:C:2013:856) at 27, which maintained that the principle of equal treatment only regulates 'the legal relationships established between the company and its shareholders which derive exclusively from the memorandum and Articles of association', with the consequence of a duty to pay damage to shareholders due to dissemination of false information.

147 C-338/06, Commission v Spain [2008] ECR I-10139. On the scope of EU principle of equal treatment see, G Strampelli, 'Rendering (Once More) the Financial Assistance Regime More Flexible' (2012) European Company and Financial Law Review 530, 545 - 546. 
law rules and principles, however, may put some obstacles in the way of secondary offers and accelerated bookbuildings.

First of all, the Italian company law regime seems to entail a strict principle of equal treatment of shareholders for listed companies. According to the Italian Civil Code, shares grant to their owners the same rights, unless the articles of association create special classes of shares. ${ }^{148}$ It is, however, still unclear whether directors of Italian companies are bound by a general principle of equal treatment of all shareholders in any circumstance. Several authors answer in the negative, holding that minorities would only be protected through fairness standards or by the prohibition of abusive oppression, not by a strict overarching principle of equality. ${ }^{149}$ Other opinions maintain that a general principle of equal treatment is implicit in companies' contractual nature and is to be derived from the rule that all shares grant the same rights. ${ }^{150}$ What is more significant for the purposes of this article is that listed companies should comply with a statutory duty of equal treatment of all security-holders, including shareholders. ${ }^{151}$ This rule was expanded in 2007 to include a right of holders of listed securities to be equally given sufficient information for exercising their corporate rights. ${ }^{152}$ Despite this provision being introduced to comply with the principle of equal treatment entailed in the second company law directive ${ }^{153}$, its scope is not limited to the topics regulated in that directive and is clearly drafted as a general principle. Therefore, listed companies that aim at issuing new shares must not disclose

148 Italian Civil Code Article 2348. See C Angelici, Parità di trattamento degli arionisti, in C Angelici and G Ferri, Studi sull'autonomia dei privati (Utet 1997) 416; F D’Alessandro, 'La seconda direttiva e la parità di trattamento degli azionisti' (1987) 31 Rivista delle Società 1.

149 See e.g. Angelici, Parità (n 148) 420 and G Marasà, Modifiche al contratto sociale, in GE Colombo and GB Portale (eds.), Trattato delle società per aẓioni (Utet 1993) vol. 7(1) 107.

150 D Preite, Abuso di maggioranza e conflitto d'interessi, in GE Colombo and GB Portale (eds.), Trattato delle società per azioni (Utet 1993) vol. 3(2) 37-42 (prohibition of discriminations in any situation deriving from the company's contract, such as lengths of speeches during a general meeting, directors' refusal to register a share purchase, based upon a company's constitution, or amendments of the original Articles of association); CM Rivolta, Diritto delle società - Profili generali, in V Buonocore and R Costi (eds.), Trattato di diritto commerciale (Giappichelli 2015) 232.

$151 \quad$ Unified Act on Finance Article 92.1.

152 Unified Act on Finance Article 92.2. as amended by legislative decree 195/2007 Article 1.

153 Directive 77/91/EEC of 13 December 1976, Article 42 (now Directive 2012/EU of the European Parliament and the Council (recast) Article 46). 
information on the envisaged transactions to selected shareholders. ${ }^{154}$ Other scholars, however, have recently argued that selective disclosures might be compatible with the principle of equal treatment when such disclosures are necessary for a transaction to succeed, provided that the recipients do not abuse inside information and signs a confidentiality agreement. ${ }^{155}$ What emerges clearly, is that a strict application of the equality principle is at odds with the flexibility required when a company addresses the capital market. Additionally, a strict application of the equality principle would lead to the conclusion that selective disclosures are not 'in the normal exercise' of directors' duties. ${ }^{156}$ Therefore, the Market Abuse Regulation is innovative in this respect, since it maintains that any disclosures of inside information that respect market sounding procedures are deemed to be made in the normal exercise of an employment, profession or duty, ${ }^{157}$ regardless of whether such disclosure violates national company law principles, such as the principle of equality.

A further question is under which circumstances Italian company law rules and principles allow domestic companies to exclude or limit preemptive rights on newly issued shares. This issue is obviously relevant for both offers of shares to the public and for allotments to selected shareholders. In general, a company can legitimately exclude or limit shareholders' preemptive rights when the 'interest of the company requires such exclusion'. ${ }^{158}$ In this regard, Italian law has increasingly simplified the disapplication of preemptive right. While older case law allowed such disapplication only when necessary to pursue the interests of the company (i.e., only if the exclusion is necessary for

154 Francesco Mucciarelli, 'L'informazione societaria: destinatari e limiti posti dalla normativa in materia di insider trading' (1999) 52 Banca borsa titoli di credito I/745, 746; U Belviso, 'L’informazione dei soci nelle società con azioni quotate' (2000) 45 Rivista delle Società 827, 861; G D’Attorre, Il principio di eguaglianza nelle società per azioni (Giuffrè 2007) 299; Macrì, Informazioni (n 46) 96;

155 P Giannelli and C Mosca, Flussi informativi tra amministratori e soci nella società quotata, tra ambiguità ed esigenze di disciplina (2012) working paper www.orizzontideldirittocommerciale.it, 35. The reason is that the principle of equal treatment protects holders of any kind of securities, not only shareholders, and is to be also applied to foreign issuers listed in an Italian regulated market, not only to Italian companies. Such a statutory principle, therefore, protects shareholders as owners of a commodity, not in their quality of members of a company. The aim of the principle of equality is, therefore, protecting a security's 'exchange value' and maximizing security-holders' 'chances' of buying and selling their shares. See FM Mucciarelli, 'Sulla parità di trattamento nelle società quotate' (2004) 49 Rivista delle Società 180, 198; D’Attorre, Il principio (n 154) 202.

156 See Giavazzi, L'abuso (n 44) 708.

157 Article 11.4. MAR.

$158 \quad$ Article 2441.5 Civil Code. 
the company's survival ${ }^{159}$, most recent authorities follow a liberal path, by accepting that shareholders' preemptive right can also be waived when this is preferable to pursuing the company's business strategies. ${ }^{160}$ Additionally, a reform of 2014 lowered the majority requirements to approve a disapplication of preemptive right. ${ }^{161}$ It is worth remembering that companies should allot new shares with a premium that reflect the company's 'real' value, ${ }^{162}$ albeit discounts from the market price are allowed to facilitate shares' allotment and seem to be quite common. ${ }^{163}$ More importantly, according to the Italian Civil Code, listed companies can issue new shares without preemptive right if their offering price is equivalent to their market price and the total amount of newly issued shares is not more than $10 \%$ of the legal capital. ${ }^{164}$ The reason is that, when the issue price is nearly equal to the shares' market price, shareholders can keep their position in the company by purchasing shares or by subscribing the newly issued shares. What is still uncertain and debated, however, is whether the

159 See, PG Jaeger, L'interesse sociale (Giuffrè 1963) 220; G Ferri, Le società (Utet 1987) 929; R Rosapepe, L'esclusione del diritto d'opzione (Giuffrè 1988) 54.

$160 \quad$ See e.g.: Cass. 13.1.1987 n. 133 (1987) Le Società 291; Cass. 23.3.1993 n. 3458 (1994) Giurisprudenza Commerciale II 372. F Di Sabato, Manuale delle società (Utet 1995) 679; GF Campobasso, Diritto commerciale (Utet 2015 ) vol. 2 511. Among legal scholars see also the intermediate theory that that the limitation of preemptive right is justified when it is necessary to pursue a specific business choice or strategy: N Robiglio, 'Delega dell'aumento del capitale e D.P.R. n. 30/1986' (1991) 35 Rivista delle Società 657, 681; FM Mucciarelli, 'Interesse sociale ed esclusione del diritto di opzione: spunti di riflessione sulla logica dell'argomentazione del giudice' (2002) 29 Giurisprudenza Commerciale I/455; E Ginevra, Diritto d'opzione, in P Abbadessa and GB Portale (eds), La società per ažioni vol. 2 (Giuffrè 2016).

161 L. 116/2014 amending Article 2441.6 Civil Code. Before 2014, such decisions had to be approved by shareholders representing at least half of the legal capital, on top of the supermajority requirements for amending the Articles (2/3 of the represented capital).

$162 \quad$ Article 2441.6 Civil Code.

163 GB Portale 'Opzione e sovrapprezzo nella novella azionaria' (1975) 1 Giurisprudenza Commerciale I/222. See, for instance, the raise of new capital of Unicredit in 2017, for shares were issued at a discount of $38 \%$ to the theoretical ex-right price ('TERP'). The TERP is the price of the shares immediately prior to announcement adjusted for the dilution caused by the rights issue.

$164 \quad$ Article 2441.4 Civil Code. 
company must necessarily issue these new shares to the public ${ }^{165}$ or can select specific investors through a private offer of shares or a bookbuilding procedure. ${ }^{166}$

In general, when a company decides to waive shareholders' preemptive right (under one of the conditions mentioned above) and to allot new shares to selected investors, instead of offering them to the public, the question arises of whether such allotment might violate any company law principles. Legal scholars seem to accept the idea that such selective allocations of shares might be allowed, provided that they are justified under one of the specific conditions mentioned above. ${ }^{167}$ Eventually, when shares are issued to directors or other 'related parties', such allotment should also respect the special proceedings for related parties' transactions, which are based upon a non-binding opinion of a committee of non-executive directors. ${ }^{168}$

Furthermore, we should address the sale of shares which are held by a company as treasury shares. This decision poses the question of whether these shares are to be offered to shareholders in a way that does not undermine their position in the company or that does not discriminate between shareholders. ${ }^{169}$ A sale of treasury shares, in particular, alters the position of shareholders in their company similarly to an issue of new shares. Therefore, despite this issue not being addressed by any statutory rules, it has been argued that treasury shares should be preemptively offered to all shareholders ${ }^{170}$ and that such a preemption right can be waived following the rules and conditions on

165 E Ginevra, 'La determinazione del prezzo e del sovrapprezzo negli aumenti di capitale sociale a pagamento', (1998) 43 Rivista delle Società 498, 519.

166 PG Marchetti, Gli aumenti di capitale, in S Rossi (ed.), Il nuovo ordinamento delle società (IPSOA 2003$) 274$ (shares can be offered either through a public offer or to selected investors); C Balp and M Ventoruzzo, 'Esclusione del diritto di opzione nelle società con azioni quotate nei limiti del dieci per cento e determinazione del prezzo di emissione’ (2004) 49 Rivista delle Società 811 (same solution); A Abu Awwad, Il diritto d'opzione nelle società quotate (Giuffrè 2013 ) 126 (shares can only be offered to selected investors).

167 See, with different general positions: D'Attorre, Il principio (n 154) 321 (when the exclusion of preemptive right is justified it does not necessarily repect shareholders' equality) and Abu Awwad, Il diritto (n 166) 190 (shareholders' equal treatment is pursued through market mechanisms).

168 CONSOB Regulation 17221/2010.

169 Directors can only sell these shares if they have been previously authorized by the general meeting of shareholders: Article 2357-bis Italian Civil Code.

170 N De Luca, La società ą̧ionista (Giappichelli 2012) 69-71 (who differentiate a right to keep shareholders' position from shareholders' equal treatment). 
the issue of new shares. ${ }^{171}$ This issue, however, is still controversial and no decision on its merit has been published so far.

Finally, it is worth mentioning that accelerated bookbuilding mechanisms are routinely used by large shareholders to sell their shares, who often sound the market out before initiating a selling proceeding. ${ }^{172}$ In this case, the main issue is whether a shareholder, who aims at selling its stake in a company, can legitimately possess inside information to be disclosed to potential buyers in order to gauge their interests in that deal, and whether companies should transfer inside information to shareholders who aim at selling their shares. As a general rule, shareholders can only receive information on their companies' affairs in circumstances indicated in specific statutory rules ${ }^{173}$ and directors must not disclose business information, unless such disclosure is statutorily allowed for specific purposes. In particular, information can circulate between a controlled entity and its controlling shareholder or among controlled companies. ${ }^{174}$ Such rules related to groups of companies have led to debate: while certain scholars have argued that the general duty of confidentiality does not apply within groups of companies ${ }^{175}$, other scholars maintain that subsidiaries do not face any duties

171 De Luca, La società (n 170) 72. For a different opinion, see D’Attorre, Il principio (n 154) 368.

172 Italian legal scholars, however, do not seem to have addressed this topic; this point is made by Giudici, Le offerte (n 116) 1071.

173 Shareholders can ask to view the shareholders' book, minutes of shareholders' general meetings (Italian Civil Code, Article 2422) and the annual accounts filed with the company's statutory seat (Italian Civil Code Article 2435 c.c.). Additionally, shareholders of listed companies can also inspect any documents filed with the company's seat regarding general meetings that have been already called: Unified Act on Finance Article 130. See, D Latella, Informazione societaria e tutela delle minoranze nelle società quotate, in M Campobasso, V Cariello, V Di Cataldo, F Guerrera and A Sciarrone Alibrandi (eds.), Società, banche e crisi d'impresa - Liber Amicorum P Abbadessa (Utet 2014) vol. 1775 (who suggests a broad interpretation of this rule that is to be applied to other cases by analogy).

$174 \quad$ Italian Civil Code Article 2381(5): executive directors should inform the board on most relevant transactions decided by controlled companies; Italian Civil Code Article 2403bis(2): the auditing board can ask the board of directors to disclose information related to controlled entities; Italian Civil Code Article 2497: liability of the controlling entity for damages suffered by controlled companies; Unified Act on Finance Article 151(1): the supervisory board of listed companies can require information directly to supervisory boards of controlled companies.

175 G Colombo, Amministraz̧ione e controllo, in S Rossi (ed.), Il nuovo ordinamento delle società (Giuffrè 2004) 182; GM Zamperetti, Il dovere di informazione degli amministratorri nella governance delle società per az̧ioni (Giuffrè 2005) 221; P Montalenti, L’informaz̧ione nei gruppi societari, in Società per az̧ioni, corporate governance e mercati finnziari (Giuffrè 2011) 265-266 (board members of a controlled entity should provide information to the controlling entity if requested); 
to provide information to the holding company. ${ }^{176}$ However, due to the concentration of share ownership of Italian listed companies, exchanges of information continuously occur between blockholders and directors. ${ }^{177}$ These circumstances were originally reflected in the Italian regime, according to which 'controlling entities' should have also complied with the duty to disclose inside information ${ }^{178}$ and insider dealing could also be committed by persons 'having a holding in the capital of the issuer' when they possess inside information. ${ }^{179}$ This situation was likely to be at odds with general company law principles ${ }^{180}$ and this provision was eventually repealed in 2012. ${ }^{181}$ Additionally, such a disclosure of information to selected shareholders risks violating the general principle of equality, which, as we have seen above, is still paramount for Italian listed companies. And yet, any shareholders who aim at selling their shares need to disclose pieces of inside information, to sound out potential investors and to allow potential buyers to assess the value of the shares ('due diligence'). Whether companies face a duty to facilitate shareholders who aim at selling their shares is a further question shrouded in uncertainty, which legal scholars, with the clear aim to facilitate such transactions, seem to accept, despite the general duty of confidentiality and the principle of shareholders' equal treatment. ${ }^{182}$ As a general principle, however, any situation in which a block trader, such as a majority shareholder, discloses information to the buyer, in order to finalize a deal and sell its shares, is not to be classified as a market sounding activity. ${ }^{183}$

176 See V Giorgi, Libertà di informazione e dovere di riservatezza degli amministratori nei gruppi di società (Giappichelli 2005) 256; N Rondinone, Società (gruppi di), Digesto delle discipline privatistiche (sezione commerciale), aggiornamento n. 5 (Utet 2009 ) 634 (members of the supervisory board of a controlled company do not face a general duty of providing information to the controlling entity).

177 B Libonati, 'Il ruolo dell'assemblea nel rapporto tra azionisti e società quotate' (2001) 46 Rivista delle Società 105.

$178 \quad$ Unified Act on Finance, Article 114.1.

179 Unified Act on Finance, Article 184.

$180 \quad$ See Giannelli and Mosca, Flussi (n 155) 16-18.

181 Legislative decree 184/2012, Article 1.10.a.

182 See L Picone, 'Trattative, due diligence e obblighi informativi delle società quotate' (2007) 57 Banca borsa titoli di credito I/236, 256-257 and U Tombari, 'Problemi in tema di alienazione della partecipazione azionaria e attività di due diligence' (2008) 58 Banca borsa titoli di credito I/65.

183 ESMA Final Report, Draft technical standards on the Market Abuse Regulation, 28 September 2015, 22 para 70. 


\subsection{The United Kingdom}

The same questions that we have analyzed with regard to the Italian regime obviously arise in a sophisticated financial market such as the British one. First of all, during securities' issuances, the question arises as to whether selective disclosures violate directors' fiduciary duties. In this respect, it is worth remembering that English law is quite reluctant to accept the idea that directors owe fiduciary duties to individual shareholders, ${ }^{184}$ unless special relation between directors and shareholders exist that give rise to fiduciary duties to individual shareholders. ${ }^{185}$ As a general principle, indeed, directors should act in good faith 'to promote the interest of the company as a whole, ${ }^{186}$ meaning present and future shareholders collectively. ${ }^{187}$ This principle, however, does not clearly answer the question as to whether (and if yes, to what extent) a general duty of shareholders' equal treatment exists.

Under English company law, as a general rule of construction, the relations between shareholders and their company are governed by a presumption of equality, unless the articles of association provides for explicit preferential treatments of certain classes of shares. ${ }^{188}$ Additionally, a possible hurdle in the way of shareholder discriminations may be erected by the proper purpose doctrine, ${ }^{189}$ which requires assessing in an objective manner whether a certain transaction - such as issuing new shares - was underpinned by an 'improper purpose' and whether such purpose was the substantial purpose envisaged by directors. ${ }^{190}$ In the words of Wilbeforce $\mathrm{J}$ in the decision Howard Smith Ltd v Ampol Petroleum Ltd, directors

are of course entitled to offer advice, and bound to supply information, relevant to the making of such a decision [launching an offer for shares], but to use their fiduciary power solely for the purpose of shifting

$184 \quad$ Percival v Wright [1902] 2 Ch 421.

185 Peskin v Anderson [2001] 1 BCLC 372; Sharp v Blank [2015] EWHC 3220 (Ch). See PL Davies and S Worthington, Gower \& Davies Principles of Modern Company Law ${ }^{10}$ (Sweet and Maxwell 2016) 467-469.

186 Companies Act 2006 s. 172(1)

187 A Keay, Direcors' duties (Jordan Publishing 2014) 141; Davies and Worthington, Gower (n 185) 465-466.

188 Birch v Cropper [1889] 14 App Cas 525 (House of Lords) (equal distribution of assets during a company's winding up).

189 Companies Act 2006, s. 171 (b): directors must 'only exercise powers for the purposes for which they are conferred'.

$190 \quad$ Howard Smith Ltd v Ampol Petroleum Ltd [1974] Ac 821 (Privy Council) 
the power to decide to whom and at what price shares are to be sold cannot be related to any purpose for which the power over the share capital was conferred upon them. ${ }^{191}$

In several decisions, directors were deemed to be acting for improper purposes when they issued new shares to selected investors or shareholders with the aim of altering the shareholder composition, defeating a takeover attempt, and ultimately fostering their control. ${ }^{192}$ Furthermore, a principle of equal treatment of all shareholders who are in the same position is entailed in the second company law directive, with regard to capital increase or decrease and share repurchases, ${ }^{193}$ and in the transparency directive, with regard to information to shareholders. ${ }^{194}$ These principles partially reflect previous common law rules, which maintain that, in a capital reduction and in a company's liquidation, assets should be repaid and losses are to be shared by respecting the ranking order of each class of shares. ${ }^{195}$

Nevertheless, English company law does not entail a general and overarching duty of equal treatment of shareholders, just a principle of fair treatment. This issue was clearly addressed in the case Mutual Life Insurance Cov The Rank Organization Ltd. ${ }^{196}$ Rank Organization was a British company that decided to issue new shares, by granting a pre-emptive right to existing shareholders. Directors of the issuing company, however, decided to exclude from the offer all shareholders who were resident in the US and Canada, in order to avoid the application of US and Canadian securities law, including a duty to register in those jurisdictions and to comply with their securities regulation. US and Canadian

$191 \quad$ Howard Smith (n 190) at 838.

192 See: Piery v S. Mills \& Co. [1920] 1 Ch 77; Punt v Symons \& Co Ltd [1903] 2 Ch 506; Hogg v Cramphorn Ltd [1967] Ch 254; Howard Smith Ltd v Ampol Petroleum Ltd [1974] Ac 821 (Privy Council); Extrasure Travel Insurances v Scattergood [2003] 1 BCLC 598. See also Madoff Securities International Ltd (in liquidation) v Raven et al. [2013] EWHC 3147 (Comm), at 199, where Popplewell J held, albeit only obiter dictum, that the proper purpose doctrine triggers a fault-based test, not an objective test.

193 Directive 77/91/EEC of 13 December 1976, Article 46. In the event of a share repurchase, the Companies Act protects shareholders by considering market repurchase as the normal method of share repurchase, which implies a general preference for equal treatment among shareholders.

194 Directive 2013/50/EU of 6 November 2011, OJ L294/13, recasting Directive 2004/109/EC, Article 17. This principle is implemented by the FCA Disclosure and Transparency Rules, 6.1.3.

195 Birch v Cropper [1889] 14 App Cas 525 (House of Lords); Re Chatterley Whitfield Collieries Ltd [1948] 2 All ER 593 (Court of Appeal).

196 [1985] BCLC 11. 
securities regulation, indeed, normally applies 'extraterritorially' to any transactions addressed to a certain number of US or Canadian residents. ${ }^{197}$ The plaintiff challenged such a decision for being 'oppressive ${ }^{198}$ due to its discriminatory nature. In rejecting this claim, Gourdin J stressed that Rank's directors acted in good faith in the interests of the company as a whole, since the risk of facing a duty to comply with foreign law in that specific case was a sufficient justification for such differential treatment. $^{199}$

This decision clearly shows that, if directors in good faith believe that special reasons exist in the interest of the members as a whole (meaning present and future shareholders), an unequal or discriminatory treatment of shareholders may be justified. Turning our attention back to market sounding activities, we can conclude that selective disseminations of information are not per se unlawful, yet they need to be justified by objective motivations in the interest of the company as a whole. The aim of gauging the interest of specific investors in order to make an offer of shares possible is likely to fall within this category, unless it is proved that directors acted in their own interests or acted without any meaningful interests of the company, and unless directors' substantial purpose was not altering the shareholder composition and fostering their power.

A further obstacle in the way of share issuances is posed by shareholders' preemptive right, aimed at protecting current shareholders against wealth transfers and a dilution of their position in the company. According to the Companies Act 2006, new 'equity securities' must be offered to existing

197 See, SJ Choi and AT Guzman, 'Internalization of securities: the dangerous extraterritoriality of American securities law' (1996) 17 Northwestern Journal of International Law \& Business 207; M Morgut, 'Extraterritorial Application of US Securities Law' (2012) 33 European Business Law Review 548.

198 Companies Act 1948, s. 210. This was the predecessor of the unfair prejudice action introduced in the Companies Act 1985, s. 459 (now: Companies Act 2006, s. 994).

199 [1985] BCLC 11 at 21. In doing so, Gourdin J applied the general common law rule that directors' fiduciary power should be exercised bona fide in the interest of the company: see Lord Greene in Re Smith and Fawcett Ltd [1942] Ch 304, at 306. The reason given by Gourdin J was followed by Arden J in Re BSB Holdings Ltd (No 2) [1996] 1 BCLC 155. Before this line of cases, see also Gaiman v the National Association for Mental Health [1970] 2 All ER 362: the Articles of a company limited by guarantee gave directors the power to request shareholders to resign; directors used this power against a shareholder, who challenged - unsuccessfully - this decision for breach of directors' fiduciary duties; Megarry J argued that 'principles of natural justice' could apply to a company formed under the Companies Acts. 
shareholders in proportion to the nominal value of capital held by each shareholder. ${ }^{200}$ The Articles or a special resolution, however, can disapply pre-emptive right, provided that such disapplication is duly authorised by the general meeting of shareholders. Such authorisations should be recommended by directors, who should issue a written statement on the reason for excluding the pre-emptive right and on the justification of the price of newly issued shares. ${ }^{201}$ Disapplications of preemptive right, therefore, do not need to be justified by special reasons in the interest of the company, provided that the specific procedure set forth in the Companies Act has been respected and directors have acted in conformity to their duties. Regarding issues of shares to the public, one of the most controversial issue is to what extent new shares can be issued at a discount to facilitate the success of their allotment. As a general fiduciary duty, directors should promote the success of the company in the interests of the members as a whole and, therefore, in principle they should obtain the best price available for newly issued shares. ${ }^{202}$ Nevertheless, allotments at discount are a normal practice to facilitate share issuances. ${ }^{203}$

Finally, we should address sales of treasury shares, which are often conducted by way of accelerated bookbuilding. In this respect, the Companies Act 2006 grants current shareholders a preemption right with regard to shares held in treasury by the issuing company, ${ }^{204}$ unless such right is waived according to the provisions set forth in the Companies Act. In this respect, it is worth mentioning that a common strategy for avoiding pre-emptive right for modest share issuances or sales is the 'vendor placing', whereby the issuing company allots shares to a third party (the 'vendor') in

200 S. 561 (1)(a) Companies Act 2006. Equity securities are (a) ordinary shares in the company (shares other than shares that as respects dividends and capital carry a right to participate only up to a specified amount in a distribution) and (b) rights to subscribe for, or to convert securities into, ordinary shares in the company (S. 560 Companies Act 2006).

201 Companies Act 2006, s. 568.

$202 \quad$ Lowry v Consolidated African Selection Trust Ltd [1940] AC 648.

203 Shearerv Bercain [1980] 3 All. E.R. 295; Re Sunrise Radio Ltd [2009] EWHC 2893 (Ch). According to FCA

listing rules, listed companies must not offer new shares at a discount of more than $10 \%$ of the 'middle market price of those shares': FCA Handbook LR 9.5.10. Additionally, we should mention that secondary offers are normally made at a discount between $30 \%$ and $40 \%$ to the TERP (such discount was between 15\% and 20\% in the 1980s): Association of British Insurers, Encouraging Equity Investment: Facilitation of Efficient Equity Capital Raising in the UK Market (July 2013 ) at 32. 204 S. 560(3) Companies Act 2006. See Ferran and Ho, Principles (n 55) 125; Davies and Worthington, Gower (n 185) 318 . 
exchange for an asset, while the vendor immediately sells these shares to the market for cash. In these cases, only a moderate discount from the market price is acceptable. ${ }^{205}$

\section{CONCLUSIONS}

This article has addressed the interaction between market sounding provisions of Article 11 MAR and national company law rules and principles in Italy and the U.K. The major point of this article is inquiring as to whether uniform rules on market sounding are at odds with national company law rules and principles, such as director fiduciary duties and principles of shareholders' fair or equal treatment. In particular, four situations have been analyzed, in which market soundings may occur: (a) when the issuer sounds the market before an initial public offer of its securities; (b) secondary offerings; (c) accelerated bookbuildings when the company acts as offeror; (d) accelerated bookbuilding when a shareholder acts as offeror.

Regarding the first case (IPO), the new uniform rules on market sounding do not contradict British and Italian company law regimes. Therefore, national company law and principles do not influence or limit the application of uniform rules provided in the Market Abuse Regulation. The new rules, however, by codifying what is already a common praxis, have the relevant effect of increasing legal certainty. Similarly, when the market is sounded by a selling shareholder, no national company law rules and principles exist in the U.K. and in Italy that may contradict uniform rules of the regulation.

By contrast, this article has shown that, when market sounding is undertaken before either secondary offerings or selling of treasury shares, national company law rules and principles might place obstacles in its way. In particular, the question arises as to whether domestic director duties and principles of shareholders' fair or equal treatment rooted in domestic company law regimes might be at odds with a uniform application of market sounding's rules. This article has shown that the Italian and British regimes diverge: while in the former director duties and the principle of shareholder equal treatment are quite rigid and might be an obstacle in the way of market soundings, English company

205 Pre-Emption group, 'Disapplying preemption right', 2015, stating that a discount of 5\% is considered acceptable, beyond which limits shareholders should be granted a claw back right. The Pre-Emption Group is a private entity, representing listed companies, investors and intermediaries, with the aim of issuing guidelines for the exercise or disapplication of the preemption right: http://www.pre-emptiongroup.org.uk/About-Us.aspx. 
law rules and principles are generally more flexible and can be adapted to financial market needs. In Italy, in particular, listed companies - despite some uncertainties as to the extension of this principle - should follow a quite strict principle of shareholders' equal treatment, which conflicts with the practice of disseminating information to selected shareholders in order to gauge their opinion on the envisaged transactions. In this regard, it is quite uncertain how the Italian regime will develop in the years to come, and we cannot rule out that the application of Article 11 MAR will be limited in order not to sacrifice general principles of company law. In the U.K., by contrast, national company law is sufficiently flexible so that it can adjust to the needs of financial markets, including issuers' aim to gauge the opinion of selected investors on an envisaged transaction. Perhaps this discrepancy between Italy and the U.K. is an outcome of the different ownership structures of their economies.

The main tenet of this article is that company law and securities regulation might follow diverging principles and might easily contradict each other. Company law regimes, which are enacted by national parliaments and courts, respond to domestic communities and constituencies; these regimes, despite significant conceptual differences that arise across jurisdictions, ${ }^{206}$ generally reflect the idea that shareholders are members of an organization aimed at running a common business, mostly so in countries such as Italy, where ownership is more concentrated and families still keep the control of most companies. Company law, in other words, seems to be partially embedded in local societies and in their power structures, ${ }^{207}$ despite the increasing harmonisation effort at the EU level. Financial markets, by contrast, are increasingly governed by uniform rules decided at a supranational level, such as the MAR; these uniform rules do not respond to national communities and constituencies, but to a broader cross-border community of business people and investors. Rules on market soundings are a typical example of this contradiction: on the one hand, a selective dissemination of information might violate basic principles of equality or director duties rooted in national company law regimes; on the other hand, such disseminations are often necessary to gauge the opinion of potential investors and to make a share issuance possible. Given the differences of ownership structures and social actors that exist across European countries, such inconsistencies are likely to be unavoidable, and yet it is to

206 See for instance N Foster, 'Company Law Theory in Comparative Perspective: England and France' (2000) 48 American Journal of Comparative Law 573.

207 On the distinction between legal institutions 'organic' to a society and its power structure and legal institutions that are merely 'mechanical' or 'technical', see O Kahn-Freund, 'On Uses and Misuses of Comparative Law' (1974) 37 Modern law Review 1. 
be hoped that national policy makers and courts become increasingly aware of such hidden discrepancies and fragmentation in order to rationally deal with them. 


\section{about ECGI}

The European Corporate Governance Institute has been established to improve corporate governance through fostering independent scientific research and related activities.

The ECGI will produce and disseminate high quality research while remaining close to the concerns and interests of corporate, financial and public policy makers. It will draw on the expertise of scholars from numerous countries and bring together a critical mass of expertise and interest to bear on this important subject.

The views expressed in this working paper are those of the authors, not those of the ECGI or its members. 


\section{ECGI Working Paper Series in Law}

\section{Editorial Board}

Editor

Consulting Editors

Editorial Assistants :
Luca Enriques, Allen \& Overy Professor of Corporate Law, Faculty of Law, University of Oxford

John Coates, John F. Cogan, Jr. Professor of Law and Economics, Harvard Law School

Paul Davies, Senior Research Fellow, Centre for Commercial Law, Harris Manchester College, University of Oxford

Horst Eidenmüller, Freshfields Professor of Commercial Law, University of Oxford

Amir Licht, Professor of Law, Radzyner Law School, Interdisciplinary Center Herzliya

Roberta Romano, Sterling Professor of Law and Director, Yale Law School Center for the Study of Corporate Law, Yale Law School

Tamas Barko , University of Mannheim

Ulrich Keesen, University of Mannheim

Mengqiao Du, University of Mannheim 


\section{Electronic Access to the Working Paper Series}

The full set of ECGI working papers can be accessed through the Institute's Web-site (www.ecgi.org/wp) or SSRN:

Finance Paper Series http://www.ssrn.com/link/ECGI-Fin.html

Law Paper Series http://www.ssrn.com/link/ECGI-Law.html 